Research Article

\title{
Effect of Soil Solution pH during the Tetracycline Intercalation on the Structural Properties of a Dioctahedral Smectite: Microstructural Analysis
}

\author{
Walid Oueslati \\ Université de Carthage, Faculté des Sciences de Bizerte, UR13ES46 Physique des Matériaux Lamellaires et Nano-Matériaux \\ Hybrides (PMLNMH), 7021 Zarzouna, Tunisia \\ Correspondence should be addressed to Walid Oueslati; walidoueslati@ymail.com
}

Received 17 May 2019; Revised 19 July 2019; Accepted 25 July 2019; Published 12 September 2019

Guest Editor: Yunpan Ying

Copyright (C) 2019 Walid Oueslati. This is an open access article distributed under the Creative Commons Attribution License, which permits unrestricted use, distribution, and reproduction in any medium, provided the original work is properly cited.

\begin{abstract}
The aim of this work is to quantitatively characterize the structural response to a chemical disruption of saturated montmorillonite crystallites by organic molecules (tetracycline (TC)), derived from pharmaceutical waste. The chemical disturbance is performed by varying the surrounding soil solution $\mathrm{pH}$. To show the effect of this chemical perturbation on the interlamellar space (IS) configuration and the hydration properties, an "in situ" XRD analysis, based on the modeling of the 00l reflections, is carried out. The "in situ" XRD analysis is performed by varying the relative humidity conditions (\%RH). FTIR SEM and BET(Brunauer-Emmett-Teller-) BJH (Barrett-Joyner-Halenda) analyses are used as complementary techniques to confirm the structural changes accompanying the intercalation process. Results showed a dependence between solution acid character and the TC adsorption mechanism. From pH values close to 7, the deprotonation of the TC molecule within IS is accelerated by an increasing \% RH rate. IR spectroscopy shows that the structure is preserved versus $\mathrm{pH}$ value and only a shift of the water deformation bands ascribed to interlamellar water molecule abundance and TC conformation is observed. The surface morphology studied by SEM shows the increase in the surface porosity by increasing the pH value. BET-specific surface area and $\mathrm{BJH}$ pore size distribution (PSD) analyses confirm the SEM observations.
\end{abstract}

\section{Introduction}

The risks associated with the presence of industrial and household waste in the soil and the environment are multiplied with the great demand for everyday consumer products. Essentially, pharmaceutical industry waste releases which include organic molecules (antibiotics and others), heavy metals, and even radioactive substances represent a serious environmental problem.

To date, various conventional and modern technologies are used for reducing the organic pollutant effect on the human health (fauna and flora). Among these technologies, we can mention the ion exchange process which is in relation to the main properties of clay mineral and chemical precipitation and adsorption [1-4]. All these methods have been developed to separate, to confine, to trap, to isolate, to eliminate, and to protect human life from contaminated effluents.
Recent studies investigated the adsorption/desorption of various organic matters on/from soil particles. These include, for example, the adsorption of antibodies, surfactants, fireretarding organics, and herbicides [5-8]. The use of these techniques is thwarted by the high cost of materials used for these purposes.

Clay, which is a material that is abundant in nature, can play an important role in the future as a geological barrier for the confinement and removal of organic pollutants in surface, ground, and wastewaters $[9,10]$. Forming part of dioctahedral phyllosilicates $2: 1$, smectites can be considered a solution for this environmental problem. Montmorillonite is a natural nanomineral (layer thickness $\sim 1.0 \mathrm{~nm}$ ) belonging to the smectite group. The intrinsic montmorillonite properties such as low permeability, high surface area, and cation exchange capacity (CEC) [11] promote its application in such context. 


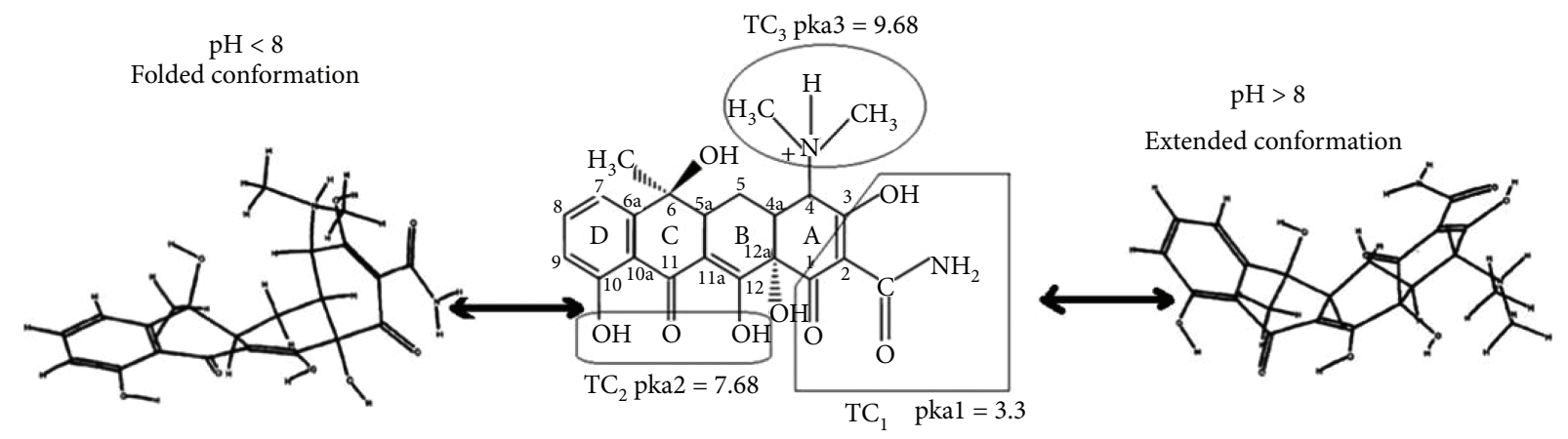

FIgURE 1: Scheme of the fully protonated tetracycline: folded conformation for $\mathrm{pH}<8$ and extended conformation for $\mathrm{pH}>8$.

The main montmorillonite structure is characterized by the isomorphic substitution presence which generates a permanent negative layer's charge. To compensate this charge deficit, exchangeable cation or organic molecules can be intercalated in the IS [12]. The montmorillonite layer structure can expand and contract its structures without crystallographic change. These expansions depend on the IS content (water/polar molecule) and the surrounding environment (relative humidity rate) [13-17].

Several studies, in relation to the use of montmorillonite in the pharmaceutical-sediment interaction context, have been, recently, realized [18-27].

Among the basic substances of antibiotics is the TC molecule. Recently, the interaction of TC, as an organic molecule, with montmorillonite has been studied, from the point of view of adsorption and intercalation, by several authors [28-34]. TCs comprise a group of natural and semisynthetic products that inhibit the synthesis of bacterial proteins. The TC chemical properties have been widely studied [35]. The protonation properties of the amine group on TC allow its cation exchange with exchanged cations of montmorillonite.

The presence of a TC molecule in IS generates (after the intercalation process) several structural ambiguities. Indeed, during the intercalation and/or adsorption process, several parameters such as chemical composition, solid/liquid ratio, $\mathrm{pH}$ dependence, soil solution composition, and environmental and atmospheric conditions come into play [36-38]. In addition, once the molecule (in our case TC) is interposed, the configuration and distribution of chemical species in IS will be disturbed and a new equilibrium (electrical, chemical, ionic, etc.) will be established. For that, a structural investigation must be directed to understanding the link between, respectively, environmental conditions, intercalation process, and structural changes.

In this regard, [37] used XRD analysis and spectroscopic methods to demonstrate that the adsorption decreases as the $\mathrm{pH}$ is increased and eventually becomes negligible at $\mathrm{pH}=11$ . In addition, [38] investigated TC intercalation onto a rectorite sample and highlighted the rectorite d-spacing increase during the intercalation process. Also, [38] demonstrate that the maximum interlayer expansion, obtained at a high $\mathrm{pH}$ value, is accompanied by an extended TC molecule conformation. Alternatively, [29] employed both simulated and experimental XRD to characterize structures, following the interlayer adsorption of OTC within Na-montmorillonite as a function of $\mathrm{pH}$. They demonstrate that the intercalation of the antibiotic species within the smectite layers at low acidic $\mathrm{pH}$ induces a random layer stacking mode. This structural behavior turns into segregation trends by increasing the $\mathrm{pH}$ value.

This work focuses on the effect of soil $\mathrm{pH}$ variation, during the TC intercalation process, on the structural properties of Na-montmorillonite. At a fixed $\mathrm{pH}$ value, "in situ" XRD analysis is performed by varying \% RH conditions. The contents of the interlamellar space along the $c^{*}$ axis are fully identified through an XRD modeling approach. The correlation of the results obtained by XRD, IR, SEM, and BET allows a quantitative description of the montmorillonite structural changes within the intercalation process.

\section{Materials and Methods}

2.1. Baseline Sample. A reference montmorillonite sample (Swy-2) (from the Source Clays Repository of the Clay Minerals Society) is used in this work [39, 40]. The halfcell structural formula is given by [41]

$$
\begin{aligned}
& \left(\mathrm{Si}_{3,923} \mathrm{Al}_{0,077}\right)\left(\mathrm{Al}_{1,459} \mathrm{Ti}_{0,018}^{4+} \mathrm{Fe}_{0,039}^{3+} \mathrm{Fe}_{0,045}^{2+} \mathrm{Mg}_{0,382}^{2+}\right) \mathrm{O}_{10} \\
& \quad \cdot(\mathrm{OH})_{2}\left(\mathrm{Ca}_{0,177}^{2+} \mathrm{Na}_{0,027}^{+}\right)
\end{aligned}
$$

Before application, a pretreatment of the natural specimen is required to guarantee a maximum dispersion. The Na-rich montmorillonite suspension is prepared according to a classical protocol detailed by $[42,43]$.

2.2. Tetracycline (TC). Tetracycline hydrochloride was delivered by PARAFARM. Depending on the solution $\mathrm{pH}$, a TC molecule undergoes protonation-deprotonation reactions which engender (03) groups and generate the formation of (04) species. The TC stock solutions are prepared just before use to avoid degradation instigated by oxygen and light. $\mathrm{NaOH}$ and $\mathrm{HCl}$ are used for $\mathrm{pH}$ adjustment. The molecular conformation change is attributed to the protonation equilibrium of the TC molecule. Indeed, for $\mathrm{pH}<8$ (from acidic to neutral solution), a twisted conformation is adopted. This situation, usually referred to as folded conformation, is explained by the release of the steric crowding between the protonated nitrogen on the dimethylamino group, $\mathrm{NH}_{4}$, and $\mathrm{OH}_{12}$. The extended conformation is displayed for $\mathrm{pH}$ values $>8$ (Figure 1) [44-46]. 

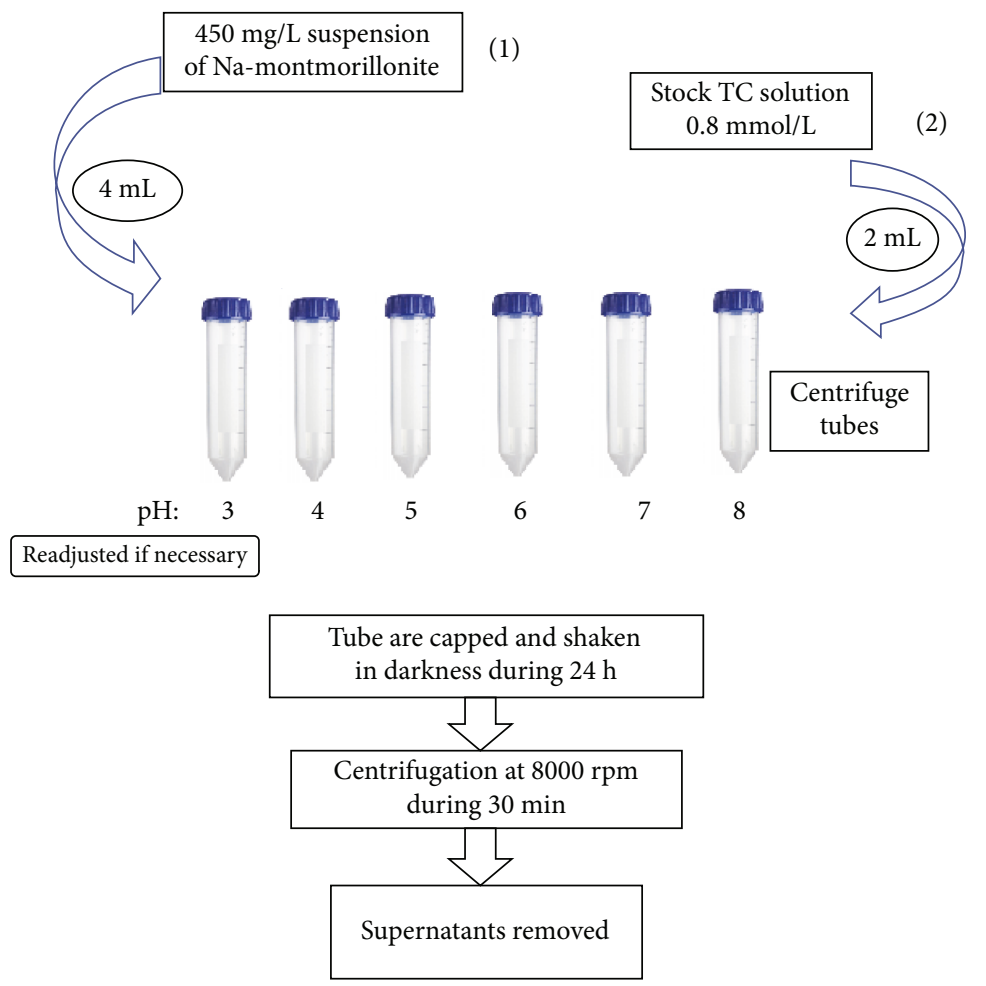

FIGURE 2: Experimental TC intercalation process under variable solution $\mathrm{pH}$.

TABle 1: The $Z$ atomic coordinates within the $2: 1$ layer framework along the $c^{*}$ axis [43].

\begin{tabular}{|c|c|c|c|c|c|c|c|c|c|c|c|}
\hline Atom type & $\mathrm{O}_{1}$ & $\mathrm{O}_{2}$ & $\mathrm{O}_{3}$ & $\mathrm{O}_{4}$ & $\mathrm{O}_{5}$ & $\mathrm{O}_{6}$ & $\mathrm{OH}_{1}$ & $\mathrm{OH}_{2}$ & $\mathrm{Si}$ & $\mathrm{Si}$ & $\mathrm{Al}$ \\
\hline Number & 2 & 1 & 2 & 2 & 1 & 2 & 1 & 1 & 2 & 2 & 2 \\
\hline $\mathrm{Zn}(\AA ̊)$ & 0 & 0.20 & 2.25 & 4.31 & 6.26 & 6.59 & 1.98 & 4.28 & 0.59 & 6.04 & 3.43 \\
\hline
\end{tabular}

2.3. Experimental Intercalation Process. The intercalation process is performed at constant TC concentration under a variable solution $\mathrm{pH}$ value. Six different $\mathrm{pH}$ values varying from acidic to neutral solution are fixed (i.e., 3, 4, 5, 6, 7, and 8). The experimental protocol is summarized in Figure 2.

2.4. In Situ X-Ray Diffraction Measurements. All experimental XRD patterns were recorded from the oriented preparations of the air-dried sample (SWy-2-TC) using a Brucker D8 Advance X-ray diffractometer at $40 \mathrm{kV}$ and $20 \mathrm{~mA}$ (CuK $\alpha$ monochromatic radiation $=0.15406 \mathrm{~nm}$ ) equipped with an Ansyco_rh-plus 2250 humidity control device coupled to an Anton Paar TTK450 chamber. For each pH value, an in situ variation of the environmental $\mathrm{RH}$, which extends from $20 \%$ to $80 \%$ (i.e., the almost saturated conditions), is carried out. The usual scanning parameters were $0.04^{\circ} 2 \theta$ as step size and $6 \mathrm{~s}$ as counting time per step over the angular range $2-40^{\circ} 2 \theta$. Samples were kept at $23^{\circ} \mathrm{C}$ in the $\mathrm{CHC}^{+}$chamber during the whole data collection. To maintain the desired $\mathrm{RH}$ rates, samples were equilibrated with their environment by a constant flow of mixed dry/saturated air.

2.5. Modeling (00l) Reflection Profiles. The XRD modeling method is used to quantify smectite hydration and ionic exchange properties as a function of a surrounding $\mathrm{RH} \%$ rate [47-50]. Theoretical XRD models are based on the algorithm developed initially by Drits and Tchoubar [51]. The $Z$ atomic coordinates within the 2:1 layer framework (tetrahedral and octahedral sheet) in the case of this study are reported in Table 1 . The $Z$ coordinates of the IS content (exchangeable cation, molecules, etc.) are optimized, during the modeling process, to improve the agreement quality. This later is controlled using the unweighted $\mathrm{Rp}$ parameter [52].

The diffracted intensity along the 001 rod belonging to the reciprocal space is given by [51]

$$
I_{00}(2 \theta)=L_{p} \operatorname{Spur}\left(\operatorname{Re}[\phi][W]\left\{[I]+2 \sum_{n}^{M-1}\left[\frac{(M-n)}{M}\right][Q]^{n}\right\}\right) \text {. }
$$

The matrix formalism behind the diffracted theoretical intensity and the fitting strategy are detailed by [47, 52]. The average position of the TC molecule within the IS is fixed at $15.40 \AA$. Regardless of the hydration state type, the $\mathrm{Na}$ exchangeable cations (per half unit cell) are positioned at the center of the IS along the $c^{*}$ axis. This configuration respects the provided literature data [53]. 
2.6. FTIR Spectroscopy. The understanding of the proposed structural models from quantitative XRD analysis requires confirmation by a complementary analysis technique. FTIR spectroscopy is used to detect the presence of groups of characteristic units in the IS $[54,55]$. These units include hydroxyl groups, dimethylamino group, silicate and aluminate anions, octahedral metal cations, and interlayer cations. FTIR spectra are recorded with $400-4000 \mathrm{~cm}^{-1}$ spectra based on a PerkinElmer Paragon 1000 PC spectrometer. The experiments are implemented by dispersing the material in $\mathrm{KBr}$ discs.

2.7. Scanning Electron Microscopy (SEM). All scanning electron micrographs are obtained from a JEOL model JSM-5400 (ETAP, Tunisia) scanning electron microscope using a beam with an acceleration of $20 \mathrm{keV}$. All samples are conducted under vacuum by the FINE COATmodel JFC_1100E installation. The studied samples are, respectively, the starting SWy-2 and the intercalated TC samples with a variable solution $\mathrm{pH}$ value.

2.8. BET and BJH Pore Size Distribution Analysis. Nitrogen sorption (both adsorption and desorption) at the clean surface of dry solid powders is used to determine the surface area (SA) and the pore size distribution (PSD) of porous materials such as montmorillonite. In this case, powders are obtained after drying each sample. Physical gas adsorption is often the technique of choice for examining the pore characteristics of materials [56]. The technique determines the amount of gas adsorbed; this is a direct indication of the porous properties and, therefore, the overall structure of the material $[57,58]$. A BET-specific surface area and PSD of the studied sample, under each $\mathrm{pH}$ value, were determined using a Quantachrome NOVA 2000e series volumetric gas adsorption instrument, which is a USA automated gas adsorption system using nitrogen as the adsorptive. Adsorption isotherms were performed at $77 \mathrm{~K}$ and at the relative pressure up to $P / P_{0} \sim 0.95$. Adsorbed nitrogen and oxygen were removed under reduced (vacuum) pressure at $100^{\circ} \mathrm{C}$ for $8 \mathrm{~h}$ before measuring SA and PSD.

The PSD was determined by the BJH method [59] to the desorption section of the isotherms of nitrogen at $77 \mathrm{~K}$, assuming the pores to be cylindrical in shape $[60,61]$.

\section{Results}

3.1. Qualitative XRD Analysis. The experimental XRD patterns showing the correlation between the $\% \mathrm{RH}$ and the $\mathrm{pH}$ of the surrounding soil solution are reported in Figure 3. The $d_{001}$ basal spacing value shifts from $18.25 \AA$ to $19.85 \AA$, by increasing $\mathrm{pH}$ from 3 to 6 , which indicates probably a complete TC adsorption process. For the high $\mathrm{pH}$ value, the obtained $d_{001}$ value indicates two-water layer (2W) hydration states which is attributed probably to a partial adsorption process of TC. The semiquantitative analysis is based on the reflection peak geometry interpretation and the investigation of the evolution of the FWHM parameter (Table 2). Indeed, the high FWHM value is obtained at $80 \% \mathrm{RH}$ for $\mathrm{pH}=5$ and at $60 \% \mathrm{RH}$ for $\mathrm{pH}=6$. This value indicates an interstratified character confirmed by the asymmetric 001 geometry peaks. All studied samples are characterized by an interstratified character due to the interlayer configuration and the external constraint imposed along the adsorption and analysis process ( $\mathrm{pH}$ and $\% \mathrm{RH})$.

Away high acidity degrees $(\mathrm{pH}=7)$ and at $60 \% \mathrm{RH}$, the XRD patterns are characterized by $d_{001}$ indicating a $2 \mathrm{~W}$ hydration state (Table 2) and the sample seems to be unaffected by the TC adsorption process. Also, this value can be interpreted by a monocationic exchange process $\left(\mathrm{Na}^{+}\right)$[40]. But, by exploiting the effect of the \%RH variation, a partial TC adsorption is confirmed for the $20 \% \mathrm{RH}$, where $d_{001}=18.54 \AA$ characteristic of high interlayer swelling which accompanied the TC adsorption.

At $\mathrm{pH}=8$ and for low $2 \theta$ angles, a minor reflection which can be attributed to the $4 \mathrm{~W}$ (four-water) hydration state with $d_{001}=22.07 \AA$ (Figure 3 ) appears. This value can be interpreted by the effect of the protonation-deprotonation reactions on the TC molecules which depends essentially on the $\mathrm{pH}$ value.

3.2. Quantitative XRD Analysis. Qualitative XRD analysis remains insufficient for a more precise description of the interlayer configuration. For that, a quantitative XRD analysis is performed to determine the structural parameter involved on the TC adsorption process. The best agreements between theoretical and experimental patterns are reported in Figure 3. The main structural parameters used to obtain a good fit are summarized in Table 3. For each model, several layer types with variable stacking mode are used in order to improve the obtained agreement between calculated and experimental patterns. This mixed-layer structure (MLS) is composed of a four-layer thickness type depending on the hydration state (i.e., $1 \mathrm{~W}(12.40 \AA)$, $2 \mathrm{~W}$ $(15.40 \AA), 3 \mathrm{~W}(18.20 \AA)$, and $4 \mathrm{~W}(21.40 \AA))$. The proposed MLS are obtained by weighted layer type populations which are supposed to have, respectively, identical chemical composition, identical layer thickness, and identical $Z$ coordinates of the atoms. The cation exchange capacity (CEC) of the starting materials is saturated by $\mathrm{Na}^{+}$and TC molecules. The XRD pattern modeling is based on the fitting strategy described by [47].

The XRD patterns obtained at $\mathrm{pH}=3$ reflect a random layer type stacking mode (R0), whereas a partial segregation (R1) is obtained for $\mathrm{pH}$ varying from 4 to 8 . Accordingly, for $\mathrm{pH} 3$ and $\mathrm{pH} 4$, a major presence of a $1 \mathrm{~W}$ layer hydration state is noted (Table 3). The $4 \mathrm{~W}$ hydration state is omnipresent along all the $\mathrm{pH}$ ranges. The clear contribution of this highly hydrated state is illustrated, respectively, at $\mathrm{pH} 5,6,7$, and 8 . The presence of the TC molecule on the interlayer space affects the 001 reflection geometry, and the appearance of broadening peaks at a low angle confirms this result. The 001 reflection is very sensitive to the content of the interlamellar space and the surrounding humidity as was observed at a high \% RH value. By increasing $\mathrm{pH}$ from 3 to 7 , there is a doublet at $\sim 12 \AA$ and $\sim 18 \AA$, which is characteristic of crystals or domains containing essentially either a $\mathrm{Na}$ or TC interlayer, respectively, both types of interlayers being mutually exclusive. By increasing 


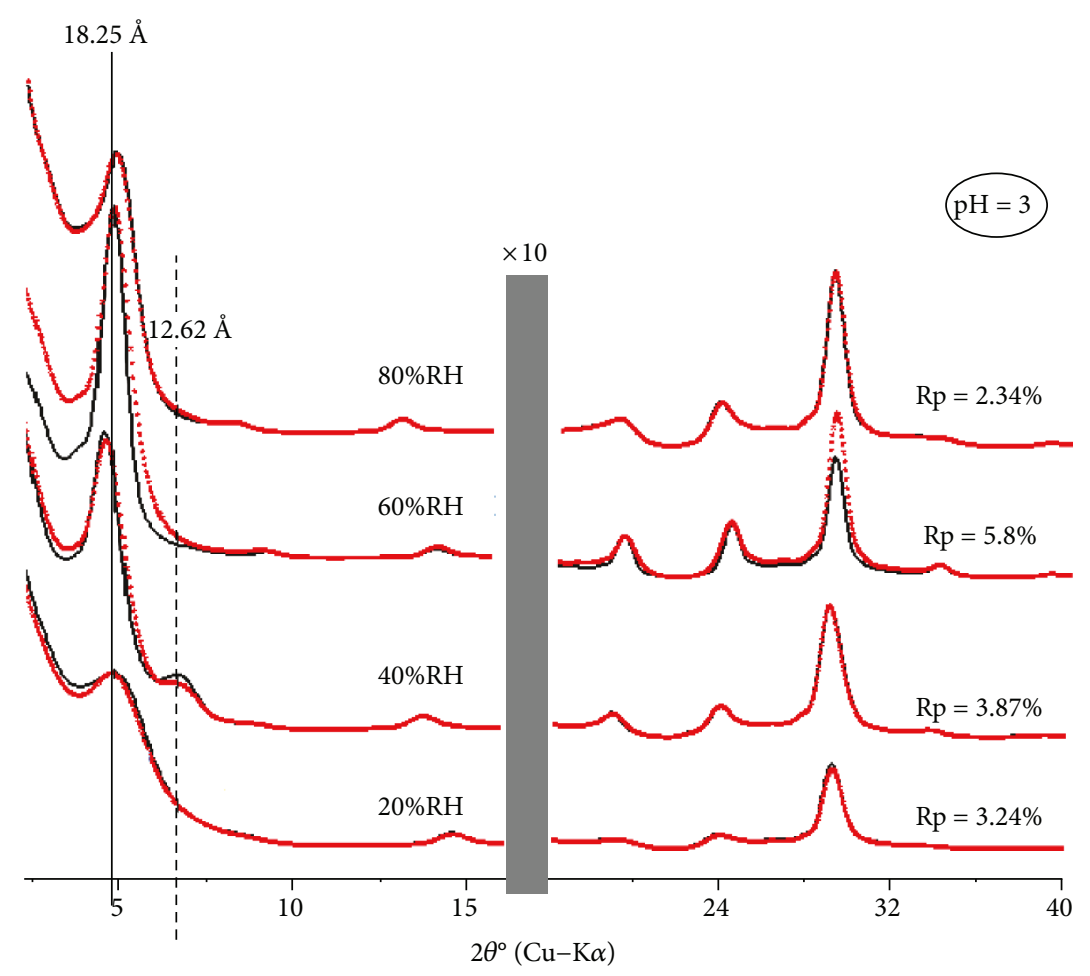

(a)

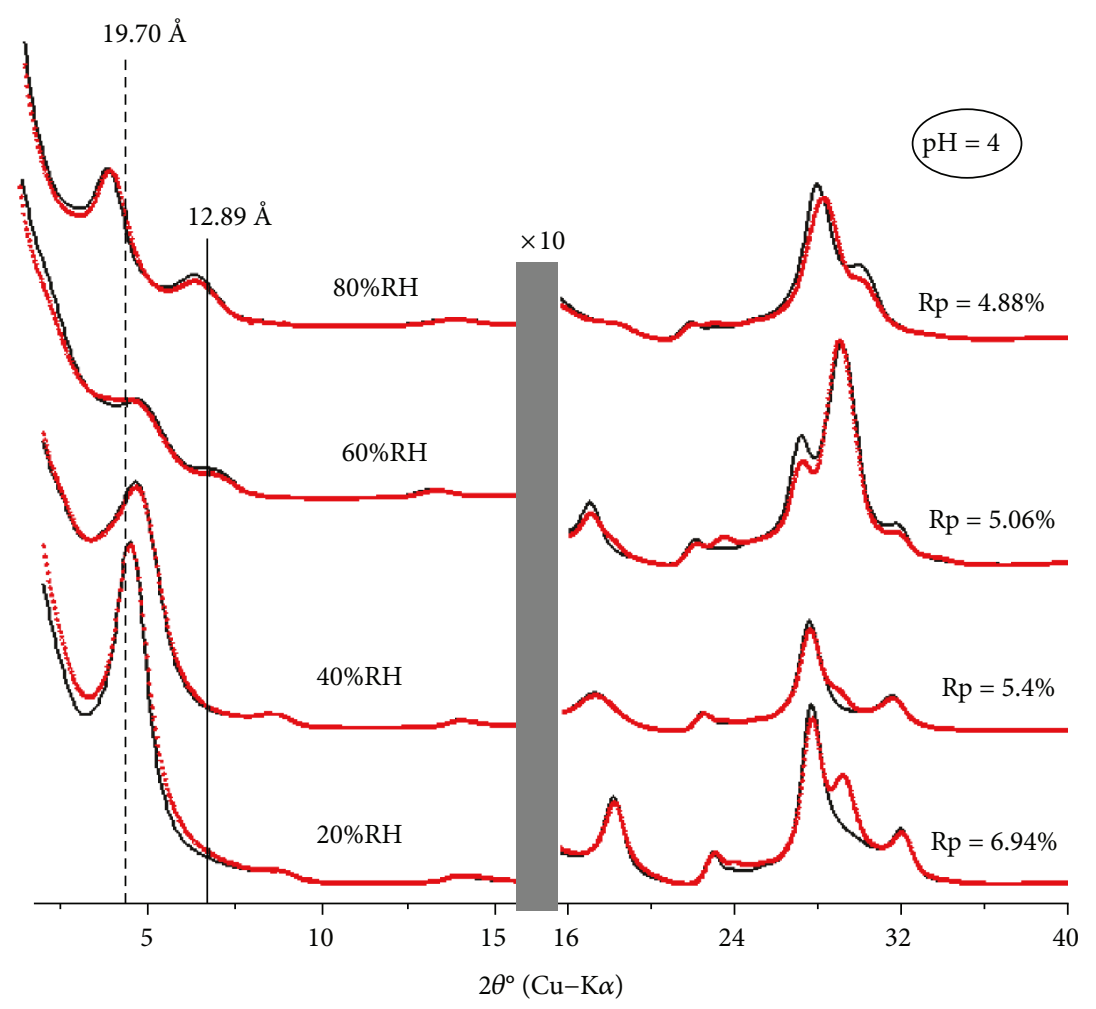

(b)

Figure 3: Continued. 


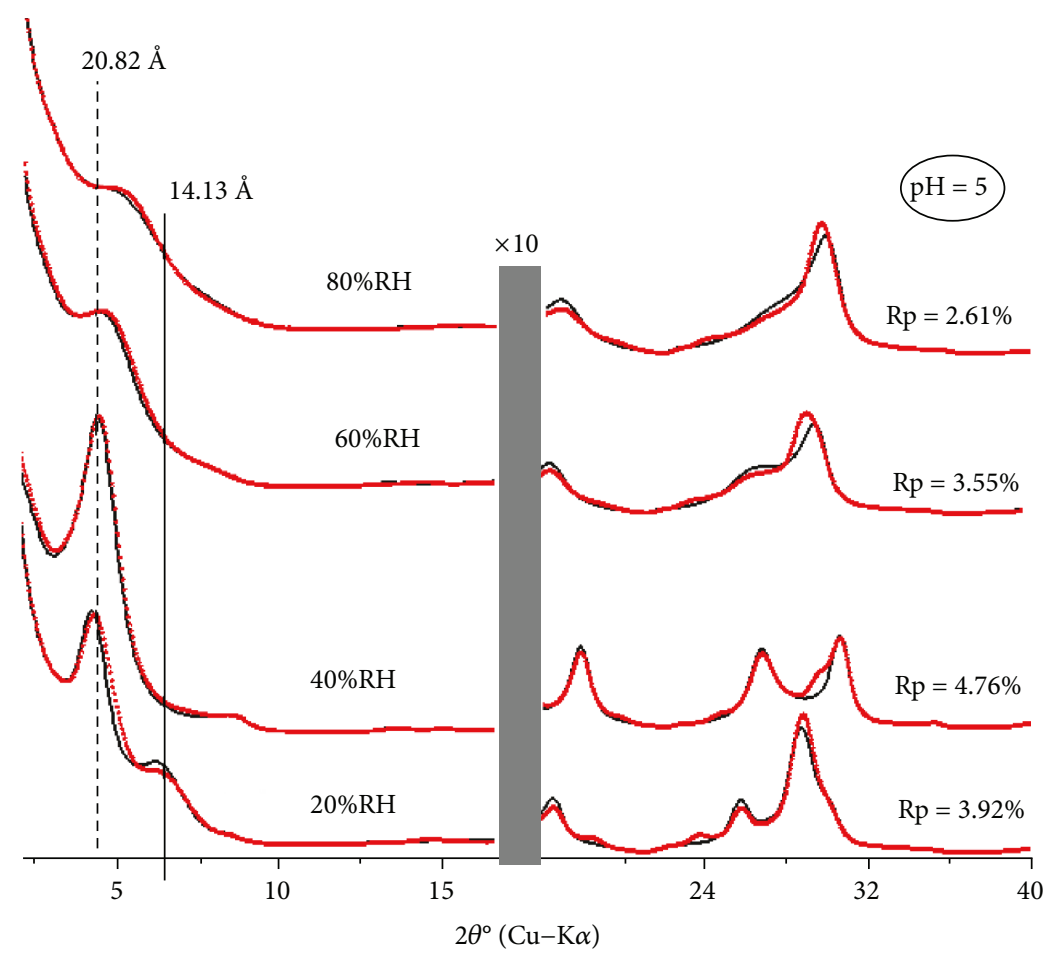

(c)

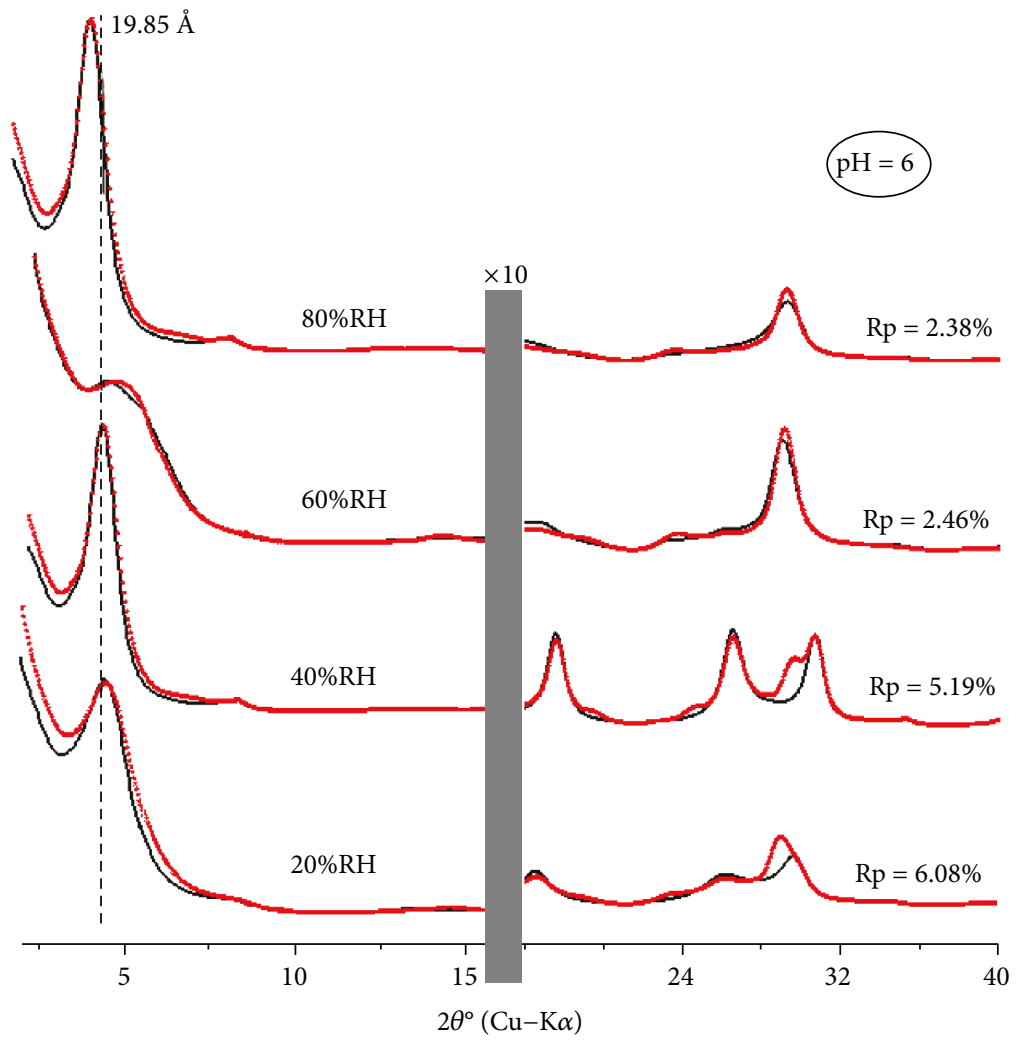

(d)

Figure 3: Continued. 
Journal of Nanomaterials

7

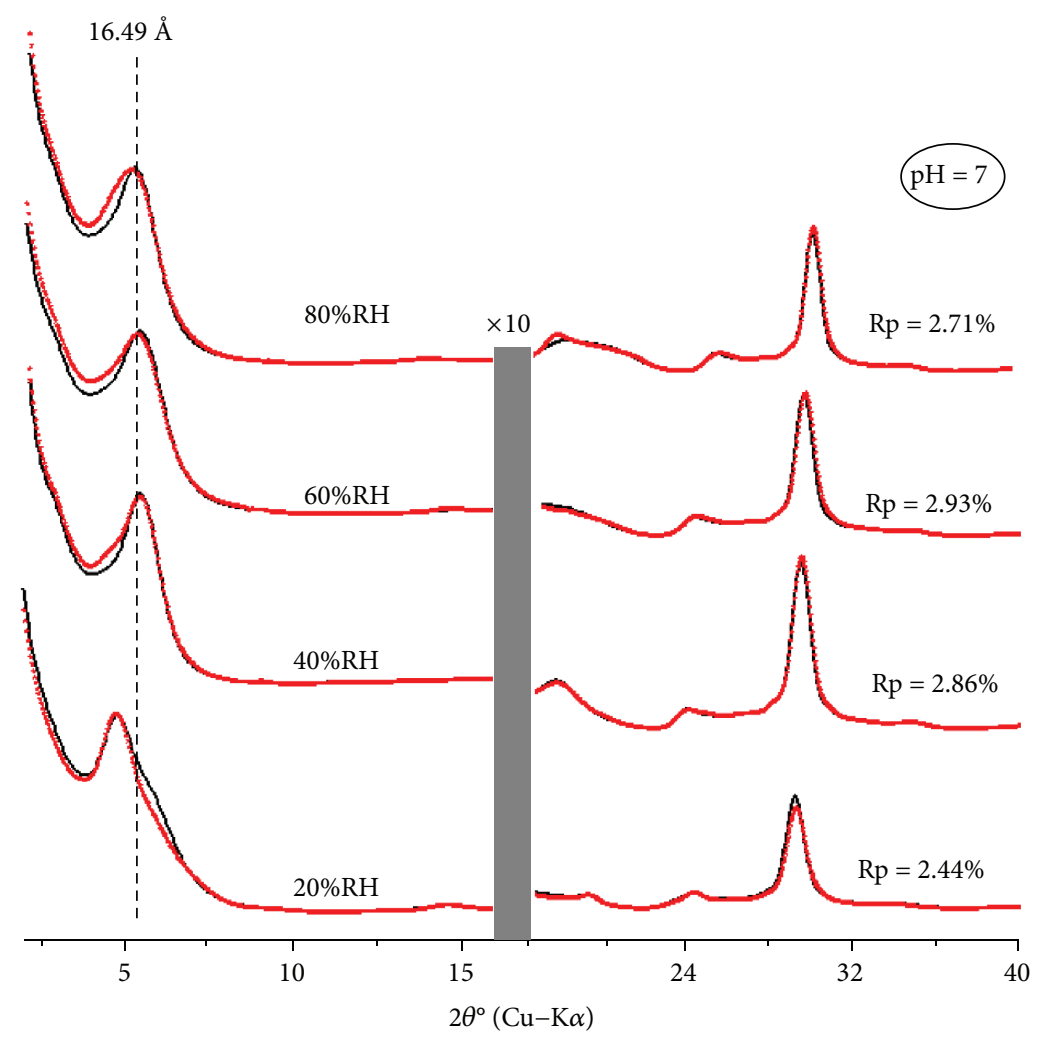

(e)

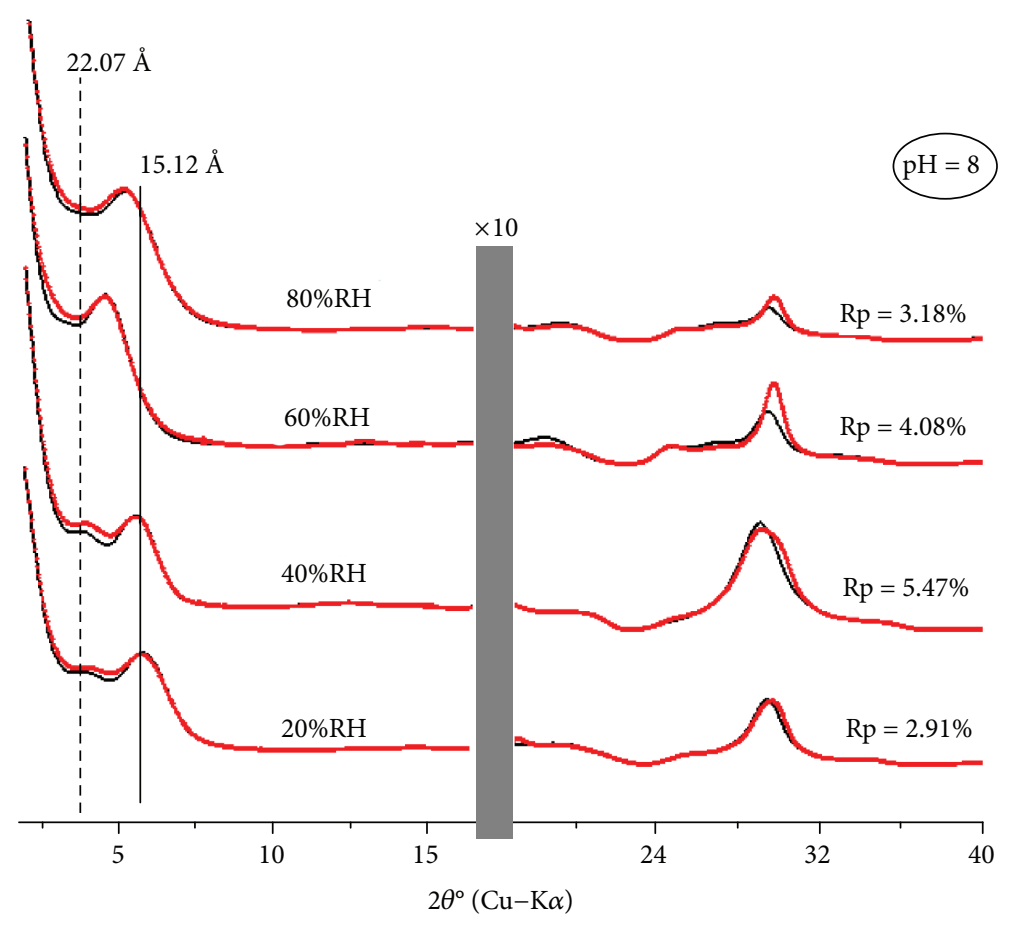

(f)

Figure 3: (a-f) The best agreement between theoretical (red line) and experimental (black line) XRD patterns obtained by varying \%RH rates under different $\mathrm{pH}$ values (3-8).

$\% \mathrm{RH}$, a modification of the relative intensities of the two peaks occurs, as indicated by a steady increase in the $\sim 18 \AA$ peak at the expense of that at $\sim 12 \AA$.
At $\mathrm{pH} \mathrm{8,} \mathrm{this} \mathrm{"law"} \mathrm{is} \mathrm{not} \mathrm{respected} \mathrm{since} \mathrm{the} 18-22 \AA$ phase (characteristic of the TC adsorption process) is reduced in favor of the $12-15 \AA$ phase (characteristic of 
TABLE 2: Qualitative XRD investigations for different studied samples versus $\mathrm{pH}$ and $\% \mathrm{RH}$ variation.

\begin{tabular}{|c|c|c|c|c|}
\hline $\mathrm{pH}$ & $\% \mathrm{RH}$ & $d_{001}(\AA)$ & FWHM $\left({ }^{\circ} 2 \theta\right)$ & Character \\
\hline \multirow{4}{*}{3} & 20 & 18.25 & 2.813 & I \\
\hline & 40 & 18.87 & 1.412 & I \\
\hline & 60 & 18.71 & 1.231 & $\mathrm{QH}$ \\
\hline & 80 & 17.66 & 1.761 & I \\
\hline \multirow{4}{*}{4} & 20 & 19.70 & 1.403 & $\mathrm{QH}$ \\
\hline & 40 & 19.02 & 2.123 & I \\
\hline & 60 & 19.53 & 2.910 & I \\
\hline & 80 & 20.06 & 3.501 & I \\
\hline \multirow{4}{*}{5} & 20 & 20.82 & 1.651 & I \\
\hline & 40 & 20.25 & 1.767 & $\mathrm{QH}$ \\
\hline & 60 & 20.06 & 2.624 & I \\
\hline & 80 & 19.36 & 3.810 & I \\
\hline \multirow{4}{*}{6} & 20 & 19.85 & 1.903 & I \\
\hline & 40 & 20.06 & 1.400 & $\mathrm{QH}$ \\
\hline & 60 & 18.25 & 3.810 & I \\
\hline & 80 & 20.43 & 3.010 & I \\
\hline \multirow{4}{*}{7} & 20 & 18.54 & 2.120 & I \\
\hline & 40 & 15.65 & 1.560 & $\mathrm{QH}$ \\
\hline & 60 & 16.47 & 1.684 & $\mathrm{QH}$ \\
\hline & 80 & 16.49 & 1.708 & I \\
\hline \multirow{4}{*}{8} & 20 & 15.12 & 2.189 & I \\
\hline & 40 & 14.15 & 2.204 & I \\
\hline & 60 & 17.51 & 1.904 & I \\
\hline & 80 & 17.38 & 2.706 & I \\
\hline
\end{tabular}

I: interstratified character; $\mathrm{QH}$ : quasihomogeneous character.

Na-exchanged montmorillonite), which can be interpreted by the deprotonation of the TC molecule. This result is confirmed by the decrease in the $4 \mathrm{~W}$ layer type abundance from $60 \% \mathrm{RH}$.

3.3. FTIR Analysis. The FTIR spectra corresponding, respectively, to TC, SWy-2-Na, and adsorbed TC under variable solution $\mathrm{pH}$ are shown in Figure 4. By comparing the characteristic vibration bands of the starting sample with those obtained after the TC adsorption process, no apparent change is observed which indicates that the adsorbed specimen does not alter the structure of the host material. This result is in concordance with XRD analysis which demonstrates that the structure is preserved and only a layer thickness variation is observed and ascribed to interlamellar water molecule abundance. All FTIR band positions $\left(\mathrm{cm}^{-1}\right)$ for SWy-2-Na without and with TC sorption are reported in Table 4.

A small difference which lies in the effect of evolution as a function of the solution $\mathrm{pH}$ is observed. Indeed, the characteristic bands attributed to the $\mathrm{OH}$ stretching and located between 3400 and $3600 \mathrm{~cm}^{-1}$ are conserved for all the studied $\mathrm{pH}$ values with a small decrease in the peak intensity probably due to the effect of the surrounding environment acidity. The Si-O stretching vibration bands located between 950 and $1100 \mathrm{~cm}^{-1}$, characteristic of the lattice vibration of the starting sample, remain present for intercalated TC samples with enlargement and decrease in the peak intensity. A small characteristic bands around $685 \mathrm{~cm}^{-1}$ are assigned to the symmetric stretching vibration $\mathrm{T}-\mathrm{O}-\mathrm{T}$ (i.e., where $\mathrm{T}=\mathrm{Si}, \mathrm{Al}$ ) which confirms the preserved structure despite the chemical perturbation [54, 55]. A characteristic band around $1600 \mathrm{~cm}^{-1}$, attributed to the vibrations of the functional groups of the $\mathrm{OH}$ - type related to the deformation of water, is observed regardless of the $\mathrm{pH}$ value. The width and intensity of this characteristic band decrease for $\mathrm{pH}$ values close to 7 . This is consistent with the results of XRD which show a transition from $3 \mathrm{~W}$ to $2 \mathrm{~W}$ hydration states. The most characteristic vibration band of TC compounds is located between 1150 and $1650 \mathrm{~cm}^{-1}$ (Table 4) and characterized by a weak intensity and width.

3.4. Scanning Electron Microscopy. The scanning electron microscope images of the natural sample (SWy-2-Na) and the intercalated TC samples as a function of the solution $\mathrm{pH}$ value are shown in Figure 5. The presence of TC molecules affects the structural morphology of the starting sample. In fact, the particle aggregation of the starting sample changes in the presence of the intercalated molecules, which induces a variable porosity as a function of the fixed solution $\mathrm{pH}$. Maximum surface porosity is observed for $\mathrm{pH}$ values close to 7.

For $\mathrm{pH}$ values ranging from 3 to 5 , the presence of TC strengthens the morphological tissue of the sample which probably indicates in terms of abundance a high intercalation level. From $\mathrm{pH}$ 6, the sample has a less collapsed structure with an increase in the pore volume. This result may be related to the effect of the low acidity of the surrounding solution or to a conformational change of the TC molecule.

3.5. BET-Specific Surface Area and PSD Analyses. The impenetrability of the nitrogen to the IS makes the BET an appropriate method to show the chemical transformation occurring on the external surface of the clay layer [62]. The structure of pores and the developed external surface area are measured using the BET method. The BET equation (both single-point and multipoint BET methods were considered) is used to calculate the surface area from nitrogen isotherms. The $\mathrm{BJH}$ method is used to determine the mean pore diameter. Table 5 shows the BET surface area and the average nanopore diameter for all the studied samples. The calculated external surface area increases by increasing the $\mathrm{pH}$ value from $13.8124 \mathrm{~m}^{2} / \mathrm{g}$ to $18.9829 \mathrm{~m}^{2} / \mathrm{g}$ (multipoint BET).

The SA measurement by the BET method (Figure 6) showed that all the studied samples had a pore distribution categorized under type II adsorption isotherm in the classification of Brunauer, Deming, Deming, and Teller (BDDT) [63] which is due probably to the mesoporous texture with large pores (in addition to the nanopores). This result is due to the TC intercalation/adsorption 
TABLE 3: Structural parameters used to reproduce experimental XRD patterns as a function of soil solution $\mathrm{pH}$ and \% RH.

\begin{tabular}{|c|c|c|c|c|c|c|c|}
\hline $\mathrm{pH}$ & $\% \mathrm{RH}$ & $\% \mathrm{MLS}$ & $1 \mathrm{~W} / 2 \mathrm{~W} / 3 \mathrm{~W} / 4 \mathrm{~W}^{\dagger}$ & $P_{\mathrm{ii}} / / W_{\mathrm{i}}$ & Physical mixture & $\begin{array}{c}Z_{\mathrm{Na}} \\
1 \mathrm{~W} / 2 \mathrm{~W} / 3 \mathrm{~W} / 4 \mathrm{~W}\end{array}$ & $M$ \\
\hline \multirow{10}{*}{3} & \multirow{3}{*}{20} & 13 & $00 / 00 / 89 / 11$ & $0.30 / / 0.30$ & R0 & \multirow{3}{*}{$09.70 / 11.10 / 12.60 / 14.10$} & \multirow{3}{*}{4} \\
\hline & & 38 & $60 / 35 / 05 / 00$ & $0.28 / / 0.28$ & R0 & & \\
\hline & & 49 & $18 / 00 / 82 / 00$ & $0.50 / / 0.50$ & R0 & & \\
\hline & \multirow{3}{*}{40} & 15 & $70 / 00 / 30 / 00$ & $0.31 / / 0.31$ & R0 & \multirow{3}{*}{$09.70 / 11.10 / 12.60 / 14.10$} & \multirow{3}{*}{4} \\
\hline & & 25 & $14 / 06 / 80 / 00$ & $0.41 / / 0.41$ & R0 & & \\
\hline & & 60 & $20 / 00 / 75 / 05$ & $0.37 / / 0.37$ & R0 & & \\
\hline & \multirow{2}{*}{60} & 45 & $00 / 16 / 84 / 00$ & $0.87 / / 0.87$ & R0 & \multirow{2}{*}{$09.70 / 11.10 / 12.60 / 14.10$} & \multirow{2}{*}{5} \\
\hline & & 55 & $11 / 00 / 85 / 04$ & $0.54 / / 0.54$ & R0 & & \\
\hline & \multirow{2}{*}{80} & 41 & $00 / 09 / 91 / 00$ & $0.38 / / 0.38$ & R0 & \multirow{2}{*}{ 09.70/11.10/12.60/- } & \multirow{2}{*}{4} \\
\hline & & 59 & $04 / 06 / 90 / 00$ & $0.27 / / 0.27$ & R0 & & \\
\hline \multirow{12}{*}{4} & \multirow{3}{*}{20} & 17 & $00 / 00 / 88 / 12$ & $0.50 / / 0.30$ & R1 & \multirow{3}{*}{ 09.70/11.10/12.60/14.10 } & \\
\hline & & 33 & $00 / 04 / 79 / 17$ & $0.55 / / 0.29$ & $\mathrm{R} 1$ & & 5 \\
\hline & & 50 & $10 / 15 / 75 / 00$ & $0.64 / / 0.34$ & $\mathrm{R} 1$ & & \\
\hline & \multirow{3}{*}{40} & 13 & $00 / 00 / 90 / 10$ & $0.47 / / 0.21$ & $\mathrm{R} 1$ & \multirow{3}{*}{$09.70 / 11.10 / 12.60 / 14.10$} & \\
\hline & & 22 & $00 / 00 / 100 / 00$ & - & - & & 6 \\
\hline & & 65 & $18 / 04 / 78 / 00$ & $0.81 / / 0.34$ & $\mathrm{R} 1$ & & \\
\hline & \multirow{3}{*}{60} & 16 & $40 / 12 / 48 / 00$ & $0.64 / / 0.29$ & $\mathrm{R} 1$ & \multirow{3}{*}{ 09.70/11.10/12.60/- } & \\
\hline & & 42 & $33 / 16 / 51 / 00$ & $0.67 / / 0.35$ & $\mathrm{R} 1$ & & 5 \\
\hline & & 42 & $40 / 00 / 60 / 00$ & $0.52 / / 0.31$ & $\mathrm{R} 1$ & & \\
\hline & \multirow{3}{*}{80} & 26 & $00 / 00 / 77 / 23$ & $0.81 / / 0.20$ & $\mathrm{R} 1$ & \multirow{3}{*}{$09.70 / 11.10 / 12.60 / 14.10$} & \\
\hline & & 29 & $40 / 35 / 15 / 10$ & $0.80 / / 0.30$ & $\mathrm{R} 1$ & & 4 \\
\hline & & 45 & $38 / 12 / 42 / 08$ & $0.72 / / 0.38$ & $\mathrm{R} 1$ & & \\
\hline \multirow{13}{*}{5} & & 35 & $00 / 33 / 55 / 12$ & $0.55 / / 0.35$ & $\mathrm{R} 1$ & & \\
\hline & 20 & 28 & 00/45/50/05 & $0.81 / / 0.54$ & $\mathrm{R} 1$ & $-/ 11.10 / 12.60 / 14.10$ & 4 \\
\hline & & 37 & $00 / 32 / 39 / 29$ & $0.64 / / 0.35$ & $\mathrm{R} 1$ & & \\
\hline & & 26 & $00 / 05 / 60 / 35$ & $0.78 / / 0.27$ & $\mathrm{R} 1$ & & \\
\hline & 40 & 14 & $00 / 00 / 38 / 62$ & $0.78 / / 0.34$ & $\mathrm{R} 1$ & $-/ 11.10 / 12.60 / 14.10$ & 5 \\
\hline & & 60 & $00 / 09 / 50 / 41$ & $0.56 / / 0.24$ & $\mathrm{R} 1$ & & \\
\hline & & 12 & 00/19/72/09 & $0.49 / / 0.18$ & $\mathrm{R} 1$ & & \\
\hline & 60 & 27 & $00 / 50 / 25 / 25$ & $0.35 / / 0.12$ & $\mathrm{R} 1$ & $-/ 1110 / 1260 / 14.10$ & 4 \\
\hline & 60 & 40 & $00 / 24 / 38 / 38$ & $0.48 / / 0.28$ & $\mathrm{R} 1$ & $-/ 11.10 / 12.60 / 14.10$ & 4 \\
\hline & & 21 & $00 / 00 / 50 / 50$ & $0.51 / / 0.37$ & $\mathrm{R} 1$ & & \\
\hline & & 30 & $00 / 20 / 80 / 00$ & $0.71 / / 0.54$ & $\mathrm{R} 1$ & & \\
\hline & 80 & 19 & $00 / 10 / 60 / 30$ & $0.77 / / 0.48$ & $\mathrm{R} 1$ & $-/ 11.10 / 12.60 / 14.10$ & 4 \\
\hline & & 51 & $00 / 10 / 55 / 35$ & $0.64 / / 0.23$ & $\mathrm{R} 1$ & & \\
\hline & 20 & 22 & $00 / 17 / 83 / 00$ & $0.81 / / 0.35$ & $\mathrm{R} 1$ & $-/ 1110 / 1260 / 14.10$ & 4 \\
\hline & 20 & 78 & $00 / 05 / 85 / 10$ & $0.79 / / 0.25$ & $\mathrm{R} 1$ & $-/ 11.10 / 12.60 / 14.10$ & 4 \\
\hline & 40 & 27 & $00 / 00 / 80 / 20$ & $0.55 / / 0.30$ & $\mathrm{R} 1$ & $-11110 / 1260 / 1410$ & 4 \\
\hline & 40 & 73 & $00 / 09 / 60 / 31$ & $0.74 / / 0.35$ & $\mathrm{R} 1$ & $-/ 11.10 / 12.60 / 14.10$ & 4 \\
\hline 6 & & 15 & $00 / 15 / 45 / 40$ & $0.78 / / 0.23$ & $\mathrm{R} 1$ & & \\
\hline & 60 & 25 & $00 / 10 / 90 / 00$ & $0.65 / / 0.38$ & $\mathrm{R} 1$ & $-/ 11.10 / 12.60 / 14.10$ & 5 \\
\hline & & 60 & 00/08/87/05 & $0.84 / / 0.40$ & $\mathrm{R} 1$ & & \\
\hline & 80 & 45 & $00 / 00 / 35 / 65$ & $0.72 / / 0.30$ & $\mathrm{R} 1$ & $-/ 1110 / 1260 / 1410$ & 4 \\
\hline & & 55 & $00 / 20 / 50 / 30$ & $0.60 / / 0.30$ & $\mathrm{R} 1$ & $-/ 11.10 / 12.00 / 14.10$ & \\
\hline
\end{tabular}


TABLE 3: Continued.

\begin{tabular}{|c|c|c|c|c|c|c|c|}
\hline $\mathrm{pH}$ & $\% \mathrm{RH}$ & $\%$ MLS & $1 \mathrm{~W} / 2 \mathrm{~W} / 3 \mathrm{~W} / 4 \mathrm{~W}^{\dagger}$ & $P_{\mathrm{ii}} / / W_{\mathrm{i}}$ & Physical mixture & $\begin{array}{c}Z_{\mathrm{Na}} \\
1 \mathrm{~W} / 2 \mathrm{~W} / 3 \mathrm{~W} / 4 \mathrm{~W}\end{array}$ & $M$ \\
\hline \multirow{9}{*}{7} & \multirow{3}{*}{20} & 20 & $00 / 44 / 52 / 04$ & $0.55 / / 0.30$ & $\mathrm{R} 1$ & \multirow{3}{*}{$-/ 11.10 / 12.60 / 14.10$} & \multirow{3}{*}{4} \\
\hline & & 70 & $00 / 45 / 55 / 00$ & $0.50 / / 0.34$ & $\mathrm{R} 1$ & & \\
\hline & & 10 & $00 / 45 / 45 / 10$ & $0.77 / / 0.41$ & $\mathrm{R} 1$ & & \\
\hline & \multirow{2}{*}{40} & 28 & $00 / 55 / 45 / 00$ & $0.80 / / 0.20$ & $\mathrm{R} 1$ & \multirow{2}{*}{$-/ 11.10 / 12.60 / 14.10$} & \multirow{2}{*}{3} \\
\hline & & 72 & $00 / 35 / 57 / 08$ & $0.76 / / 0.25$ & $\mathrm{R} 1$ & & \\
\hline & \multirow{2}{*}{60} & 35 & $00 / 48 / 48 / 04$ & $0.55 / / 0.22$ & $\mathrm{R} 1$ & \multirow{2}{*}{$-/ 11.10 / 12.60 / 14.10$} & \multirow{2}{*}{5} \\
\hline & & 65 & $00 / 68 / 32 / 00$ & $0.50 / / 0.38$ & $\mathrm{R} 1$ & & \\
\hline & \multirow{2}{*}{80} & 38 & $00 / 50 / 50 / 00$ & $0.55 / / 0.18$ & $\mathrm{R} 1$ & \multirow{2}{*}{$-/ 11.10 / 12.60 / 14.10$} & \multirow{2}{*}{4} \\
\hline & & 62 & $00 / 65 / 30 / 05$ & $0.80 / / 0.26$ & $\mathrm{R} 1$ & & \\
\hline \multirow{12}{*}{8} & \multirow{3}{*}{20} & 25 & $00 / 55 / 45 / 00$ & $0.71 / / 0.21$ & $\mathrm{R} 1$ & \multirow{3}{*}{$-/ 11.10 / 12.60 / 14.10$} & \multirow{6}{*}{5} \\
\hline & & 35 & $00 / 40 / 10 / 50$ & $0.64 / / 0.28$ & R1 & & \\
\hline & & 40 & $00 / 48 / 12 / 40$ & $0.55 / / 0.24$ & R1 & & \\
\hline & \multirow{3}{*}{40} & 35 & $00 / 42 / 18 / 40$ & $0.49 / / 0.30$ & $\mathrm{R} 1$ & \multirow{3}{*}{$-/ 11.10 / 12.60 / 14.10$} & \\
\hline & & 35 & $00 / 50 / 00 / 50$ & $0.62 / / 0.15$ & R1 & & \\
\hline & & 30 & $00 / 55 / 00 / 45$ & $0.81 / / 0.30$ & $\mathrm{R} 1$ & & \\
\hline & \multirow{3}{*}{60} & 25 & $00 / 49 / 40 / 11$ & $0.50 / / 0.30$ & R1 & \multirow{3}{*}{$-/ 11.10 / 12.60 / 14.10$} & \multirow{3}{*}{4} \\
\hline & & 28 & $00 / 55 / 45 / 00$ & $0.54 / / 0.33$ & $\mathrm{R} 1$ & & \\
\hline & & 47 & $00 / 45 / 43 / 12$ & $0.64 / / 0.18$ & $\mathrm{R} 1$ & & \\
\hline & \multirow{3}{*}{80} & 42 & $00 / 40 / 60 / 00$ & $0.66 / / 0.30$ & $\mathrm{R} 1$ & \multirow{3}{*}{$-/ 11.10 / 12.60 / 14.10$} & \multirow{3}{*}{4} \\
\hline & & 20 & $00 / 46 / 50 / 04$ & $0.50 / / 0.27$ & $\mathrm{R} 1$ & & \\
\hline & & 38 & $00 / 55 / 45 / 00$ & $0.55 / / 0.16$ & $\mathrm{R} 1$ & & \\
\hline
\end{tabular}

Note: $4 \mathrm{~W}, 3 \mathrm{~W}, 2 \mathrm{~W}$, and $1 \mathrm{~W}$ are attributed to the layer hydration state. R0 and R1 describe mixed-layer structures with random interstratifications or with partial segregation, respectively. $*$ indicates homogenous structure. $P_{i j}$ is the junction probability of layer type $\mathrm{j}$ to follow layer type $\mathrm{i}$, and $W_{i}$ abundances of layer type $\mathrm{i}$. In this case, $\mathrm{i}$ is $\mathrm{Na}$ and $\mathrm{j}$ is TC, wherein four equations are used: $W_{\mathrm{Na}}+W_{T C}=1$ (1), $P_{\mathrm{Na}-\mathrm{Na}}+P_{\mathrm{Na}-\mathrm{TC}}=1(2), P_{T C-T C}+P_{T C-N a}=1$ (3), and $W_{N a}$ $P_{\mathrm{Na}-\mathrm{TC}}=W_{T C} P_{T C-\mathrm{Na}}(4) . Z_{\mathrm{Na}}$ : position of exchangeable cations per half unit cell calculated along the $c^{*}$ axis. $Z_{T C}$ : average position of the adsorbed TC molecule is fixed at $15.40 \AA$. . $M$ : average layer number per stacking.

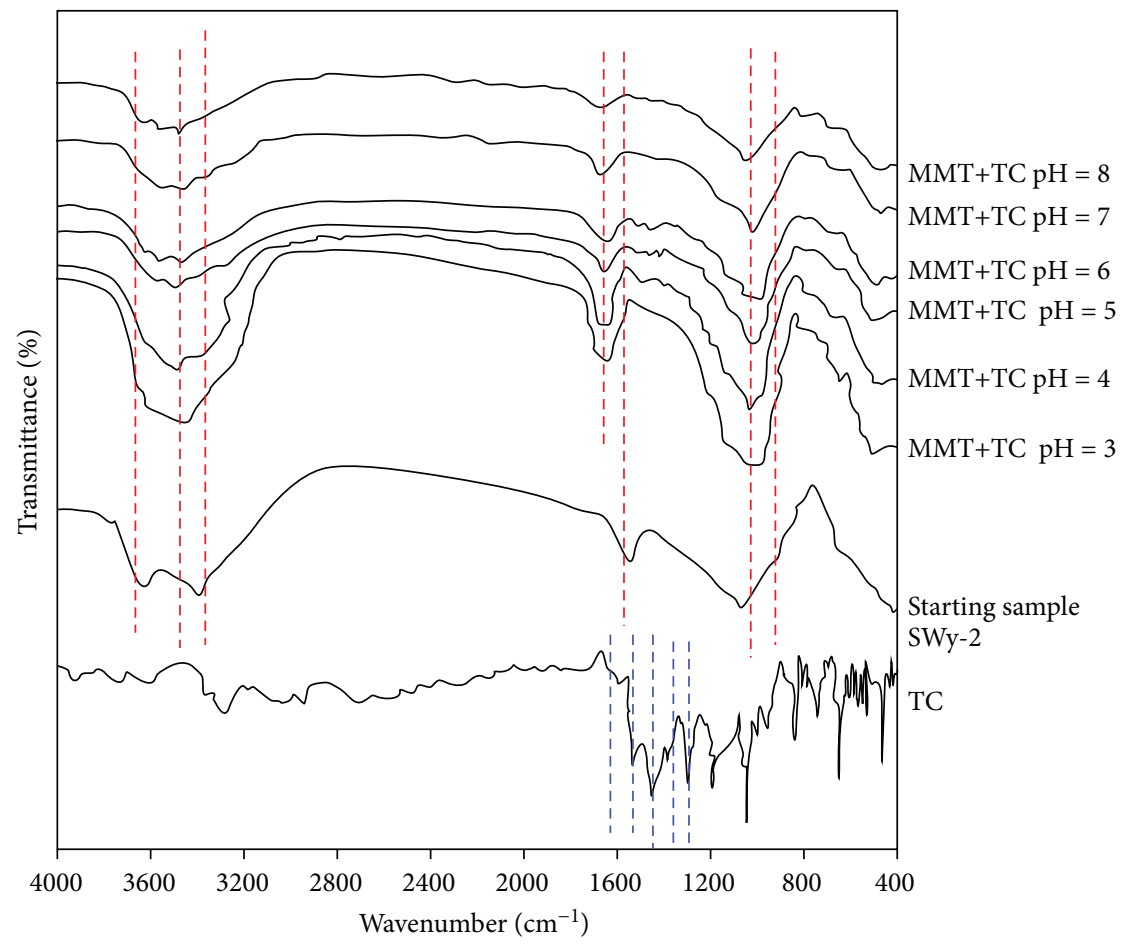

FIGURE 4: Transmittance IR spectra obtained, respectively, for TC, SWy-2-Na, and TC intercalated sample under a variable solution pH value. 
TABLE 4: FTIR band position $\left(\mathrm{cm}^{-1}\right)$, respectively, for TC, Na-montmorillonite (SWy-2-Na), and TC sorption versus pH.

\begin{tabular}{|c|c|c|}
\hline Sample & FTIR band position & Possible band assignment [38] \\
\hline \multirow{5}{*}{ TC } & 1627 & $v(\mathrm{CO} 1), v($ amid-NH $), v(\mathrm{CO} 3), v(\mathrm{C} 2 \mathrm{C} 3), \delta(\mathrm{OH} 10,12)$ \\
\hline & 1572 & $\delta($ amid-NH $), \delta($ amine- $\mathrm{NH}), v($ amid-CO $), v(\mathrm{C} 2 \mathrm{C} 3), v(\mathrm{CO} 3)$ \\
\hline & 1446 & $\delta(\mathrm{OH} 10,12), \delta(\mathrm{CH} 7,8,9), v(\mathrm{D}), v(\mathrm{CO} 10, \mathrm{CO} 11), v(\mathrm{C} 11 \mathrm{C} 11 \mathrm{a}, \mathrm{C} 11 \mathrm{aC} 12), \delta(\mathrm{OH} 12 \mathrm{a}), \delta(\mathrm{CH} 36)$ \\
\hline & 1350 & $\begin{array}{c}v(\text { amid-C,C2 }), v(\mathrm{C} 3, \mathrm{C} 4), \delta(\mathrm{CH} 4 \mathrm{a}, 5), \delta(\mathrm{CH} 36), \delta(\mathrm{OH} 12 \mathrm{a}), \delta(\operatorname{amid}-\mathrm{NH}), v(\text { amid-CN }) \\
\delta(\mathrm{OH} 10), v(\mathrm{C} 6 \mathrm{aC} 10 \mathrm{a}, \mathrm{C} 6 \mathrm{aC} 7)\end{array}$ \\
\hline & 1310 & $\begin{array}{c}\delta(\mathrm{OH} 10,12), \delta(\mathrm{CH} 4,4 \mathrm{a}, 5,5 \mathrm{a}), v(\mathrm{C} 5 \mathrm{aC} 11 \mathrm{a}), v(\mathrm{C} 1 \mathrm{C} 2), v(\mathrm{C} 9 \mathrm{C} 10, \mathrm{C} 10 \mathrm{C} 10 \mathrm{a}, \mathrm{C} 10 \mathrm{aC} 11) \\
v(\mathrm{CO} 11,12), v(\mathrm{CO} 3), \delta(\mathrm{CH} 7,8,9)\end{array}$ \\
\hline \multirow{6}{*}{$\begin{array}{l}\text { Na-montmorillonite } \\
(\mathrm{SWy}-2-\mathrm{Na})\end{array}$} & 3620 & OH stretching of structural hydroxyl groups \\
\hline & 3542 & $\mathrm{OH}$ stretching of water coordinated to $\mathrm{Al}$ and $\mathrm{Mg}$ \\
\hline & 3415 & $\mathrm{OH}$ stretching of adsorbed water \\
\hline & 1656 & $\mathrm{OH}$ deformation of water \\
\hline & 1035 & Si-O stretching \\
\hline & 980 & Si-O stretching \\
\hline \multirow{6}{*}{$\begin{array}{l}\mathrm{MMT}+\mathrm{TC} \\
\text { For } \mathrm{pH}: 3 \rightarrow 8\end{array}$} & 3621 & $\mathrm{OH}$ stretching of structural hydroxyl groups \\
\hline & 3542 & $\mathrm{OH}$ stretching of water coordinated to $\mathrm{Al}$ and $\mathrm{Mg}$ \\
\hline & 3417 & $\mathrm{OH}$ stretching of adsorbed water \\
\hline & 1638 & $\mathrm{OH}$ deformation of water \\
\hline & 1048 & Si-O stretching \\
\hline & 980 & Si-O stretching \\
\hline
\end{tabular}

process. Also, because of the ability of nitrogen to cover only the outer primary surface area but not the IS, an asymptotic approach to limiting quantity is observed in nitrogen isotherms. Indeed, it is necessary to differentiate between external, internal, and interlamellar surface areas for clays.

The surface area concept does not give a complete textural description in the case of clay specimen; for that, a pore size (PS) and a pore size distribution (PSD) are necessary. The PSD in the mesopore region was determined by the $\mathrm{BJH}$ method assuming

(i) the shape of the pores with radius $(r)$ approximatively half of its width is cylindrical [61]

(ii) the radii $(r)$ of mesopores assumed to be cylindrical corresponding to $V$ values were calculated from the corrected Kelvin equation by the use of $P / P_{0}$ values [64]

(iii) the specific micropore, mesopore, and macropore volumes (namely, $V_{\mathrm{Mi}}, V_{\mathrm{Me}}$, and $V_{\mathrm{Ma}}$ all in $\mathrm{mL} / \mathrm{g}$, respectively) are defined as the volumes of micropores, mesopores, and macropores including nanopores in one gram solid

(iv) the presence of macropores has a low effect on the adsorptive properties of a solid [65]

(v) the adsorption capacity as liquid nitrogen volumes which were estimated from desorption data at the relative equilibrium pressure $\left(P / P_{0}\right)$ less than 0.96 is taken as the specific micro-mesopore volumes $\left(V=V_{\mathrm{Mi}}+V_{\mathrm{Me}}\right)$ (vi) $P_{0}$ and $P$ are the vapor pressure of the bulk liquid nitrogen and equilibrium pressure of desorption at the liquid nitrogen temperature $(\sim 77 \mathrm{~K})$

The $V-r$ (cumulative pore volume vs. pore radius) plots are called mesopore PSD and given in Figure 7.

The estimated $V_{\mathrm{Mi}}$ and $V_{\mathrm{Me}}$ can be obtained by the intercepts of the extrapolations of each PSD curve related to each sample [66]. The $V_{\mathrm{Me}}$ increase from 0.027 to $0.036 \mathrm{~mL} / \mathrm{g}$ by increasing soil solution $\mathrm{pH}$ during the intercalation/adsorption process.

The radius derivative of the $V-r$ curve for all samples is given in Figure 8 where the maximum mesopore volume $(0.000948 \mathrm{~mL} / \mathrm{g})$ is obtained from $\mathrm{pH} 7$ and the mesopore radii varied between 1.5 and $16 \mathrm{~nm}$. The increase in the average pore diameter from a micropore with a width smaller than $2 \mathrm{~nm}$ is attributed to the reduction of microporous distribution in favor of mesoporous distribution. The porosity investigation using the BET-BJH method confirms observations obtained by SEM indicating changes on the morphological properties versus increasing $\mathrm{pH}$ rate. This transformation can be interpreted by a possible TC molecule conformation change.

\section{Discussion}

The TC intercalation on the montmorillonite interlayer is confirmed by the layer thickness variation. This result is demonstrated by several works [19-21, 37]. The layer thickness evolution is ascribed to the interlamellar space organization between interlayer species, essentially water molecules, exchangeable sodium, and TC molecules. 


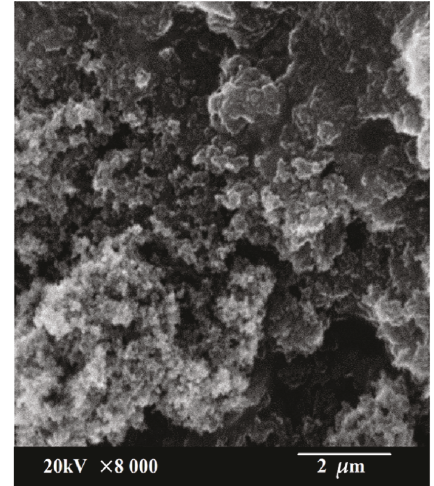

(a) Starting Na-montmorillonite (MMT)

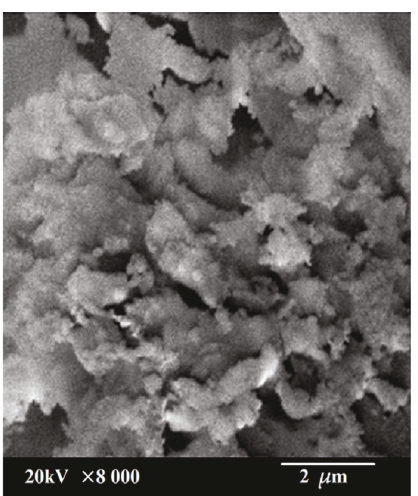

(d) $\mathrm{MMT}+\mathrm{TC} \mathrm{pH}=5$

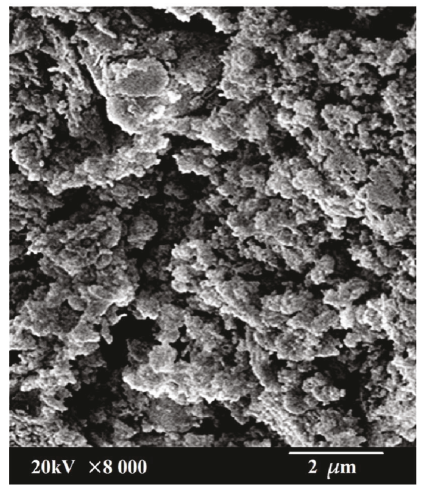

(b) $\mathrm{MMT}+\mathrm{TC} \mathrm{pH}=3$

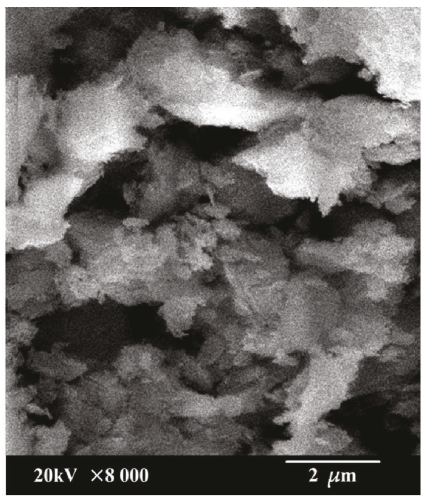

(e) $\mathrm{MMT}+\mathrm{TC} \mathrm{pH}=6$

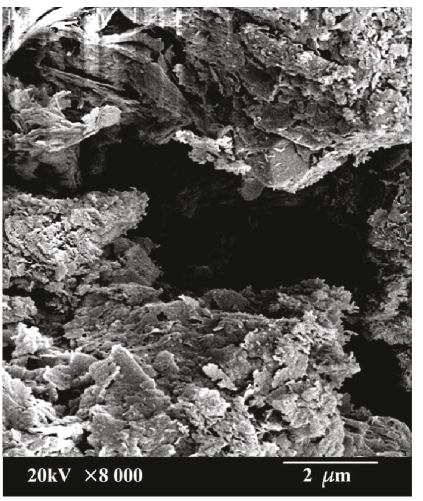

(g) $\mathrm{MMT}+\mathrm{TC} \mathrm{pH}=8$

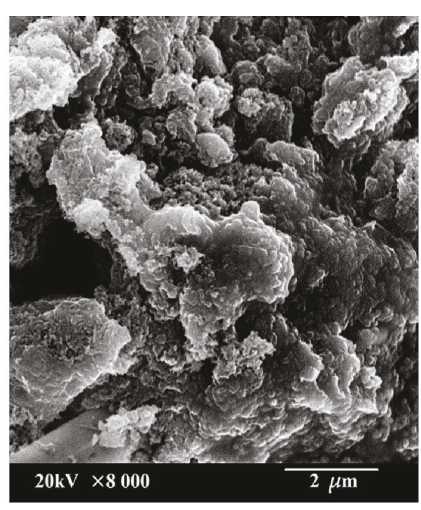

(c) $\mathrm{MMT}+\mathrm{TC} \mathrm{pH}=4$

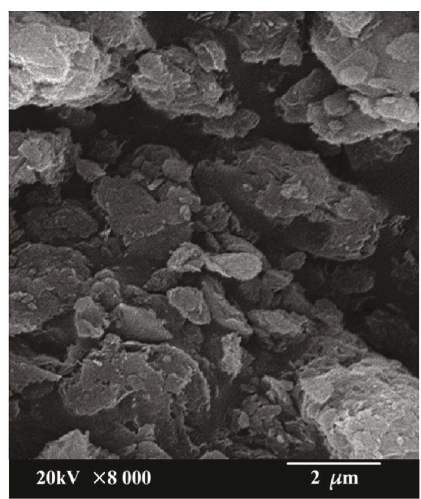

(f) $\mathrm{MMT}+\mathrm{TC} \mathrm{pH}=7$

FIGURE 5: SEM analysis in the case of the starting sample and the intercalated sample under variable solution $\mathrm{pH}$.

TABLE 5: $\mathrm{SA}_{\mathrm{BET}}$ (single-point and multipoint BET) and $\mathrm{BJH}$ method average pore diameter.

\begin{tabular}{lccc}
\hline Sample & $\begin{array}{c}\mathrm{SA}_{\text {BET }}\left(\mathrm{m}^{2} / \mathrm{g}\right) \\
\text { Single-point BET }\end{array}$ & $\begin{array}{c}\mathrm{SA}_{\text {BET }}\left(\mathrm{m}^{2} / \mathrm{g}\right) \\
\text { Multi-point BET }\end{array}$ & $\begin{array}{c}\text { Average nanopore diameter (nm) } \\
\text { B)H method }\end{array}$ \\
\hline MMT+TC_pH3 & 13.7856 & 13.8124 & 3.7102 \\
MMT+TC_pH4 & 13.9145 & 13.9735 & 3.6905 \\
MMT+TC_pH5 & 14.0864 & 14.3147 & 3.7289 \\
MMT+TC_pH6 & 15.8261 & 15.9432 & 3.7305 \\
MMT+TC_pH7 & 17.9425 & 18.1287 & 3.7646 \\
MMT+TC_pH8 & 18.9461 & 18.9829 & 3.7724 \\
\hline
\end{tabular}




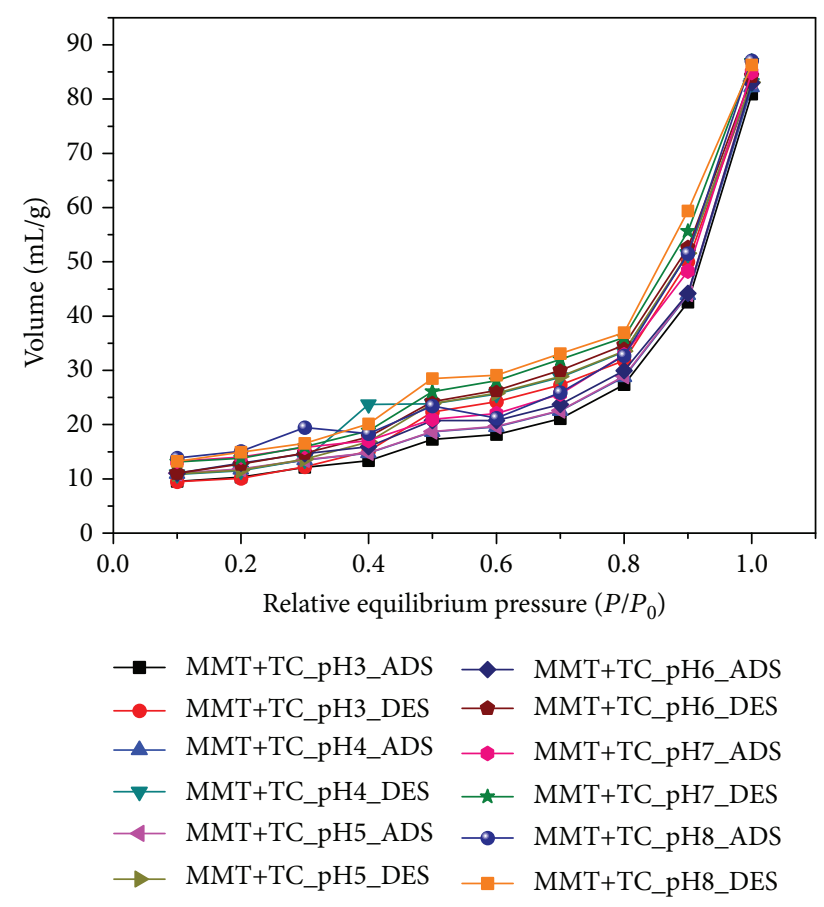

Figure 6: Nitrogen adsorption-desorption isotherms of montmorillonite-exchanged TC under varying soil solution $\mathrm{pH}$. MMT: montmorillonite; TC: tetracycline; ADS: adsorption; DES: desorption.

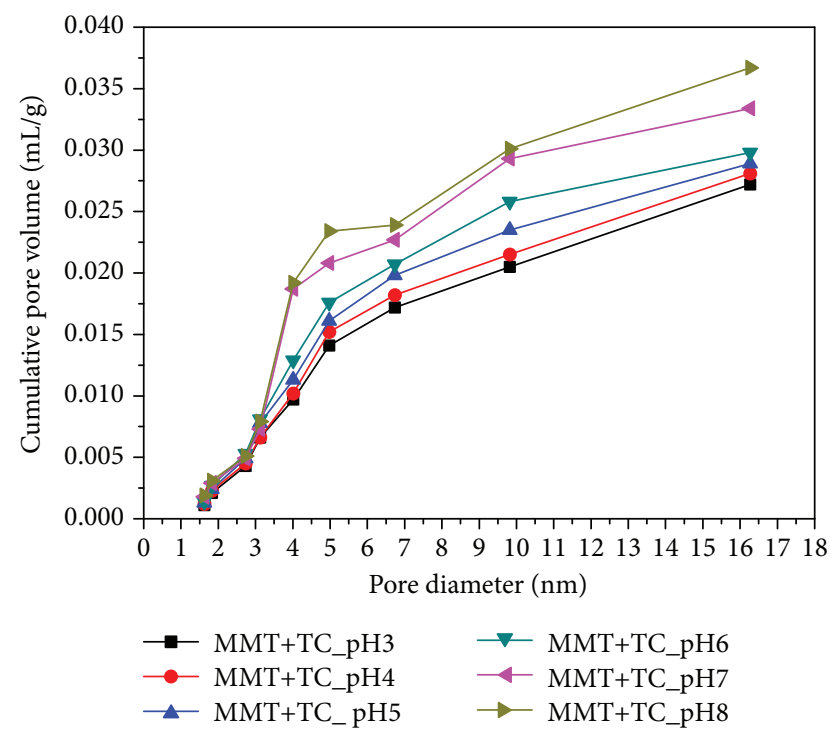

FIgURE 7: The pore size distribution curve in the case of montmorillonite-exchanged TC under varying soil solution $\mathrm{pH}$.

Based on the theoretical XRD analysis, it is shown that this variation is mainly affected by the nature and/or the amount of the intercalated water. [29] use the XRD modeling approach in order to characterize the $\mathrm{pH}$-dependent intercalation of TC within montmorillonite, and they demonstrate that $\mathrm{pH}$, when increased, is responsible of the reduction of the intercalated TC amounts. Also, they reveal that the $\mathrm{pH}$ -

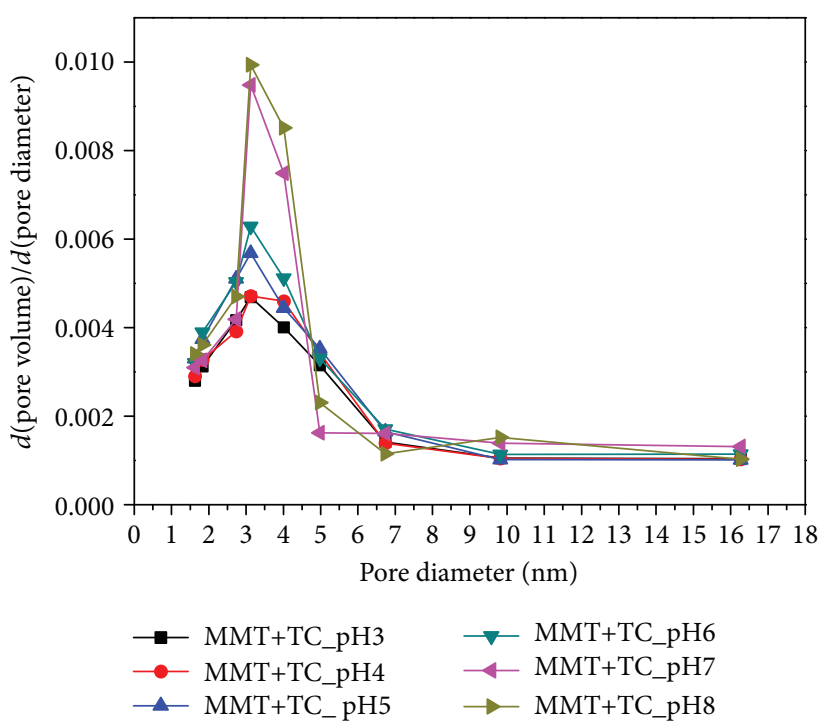

Figure 8: The derivative pore size distribution curve in the case of montmorillonite-exchanged TC under varying soil solution $\mathrm{pH}$.

dependent change in the access of TC to the clay interlayers is not positively correlated with TC speciation, thus corroborating a possible correlation with changes in the clay surface chemistry as $\mathrm{pH}$ increases. In this work, another point of view is addressed, the correlation between the environment of the material and the soil solution $\mathrm{pH}$ in order to quantify the water levels present in the interlamellar space.

The investigation of the water molecule evolution versus the soil solution $\mathrm{pH}$ (Figure 9) shows quasiabsence of the $4 \mathrm{~W}$ hydration state at $\mathrm{pH}=3$ and $\mathrm{pH}=7$, despite the high moisture contents at $\mathrm{RH}=80 \%$. For the same $\mathrm{pH}$ range, the $3 \mathrm{~W}$ hydration state dominates the structure indicating probably a great abundance, within the "clay particle" of the sheets presenting a complete intercalation of TC molecules. This result is confirmed by the presence of the highly hydrated state (i.e., $3 \mathrm{~W}$ ) even for the lowest humidity rate which is the case for all investigated $\mathrm{pH}$ values except $\mathrm{pH}=8$. A notable effect of the $\mathrm{pH}$ variation is shown for the $1 \mathrm{~W}$ hydration state which disappears from $\mathrm{pH}=4$. This may be due to a new interlayer organization where a layer "population" with partial or total CEC saturation with the TC molecule is noted. For $\mathrm{pH}=7$ and 8 , a major $2 \mathrm{~W}$ layer abundance manifests which is attributed to the TC conformation change demonstrated by the work of $[29,44,46]$. The proposition is confirmed by XRD analysis at $\mathrm{pH}=8$ where a declared $4 \mathrm{~W}$ hydration state, characterized by $d_{001}=22.07 \AA$, is observed. This result agrees with those obtained by [21]. Indeed, they demonstrate that TC located in the interlayer spacing increase the $d_{001}$ basal spacing from nearly $13.7 \AA$ to nearly 22.0 ̊. Physically, this result may have a logical explanation due to the increase in the TC molecule freedom degree within the interlayer space. This increase is attributed to the presence of $4 \mathrm{~W}$ layers (at minimum) and a probable decrease in the concentration of exchanged TC molecules which is in concordance with earlier works. 


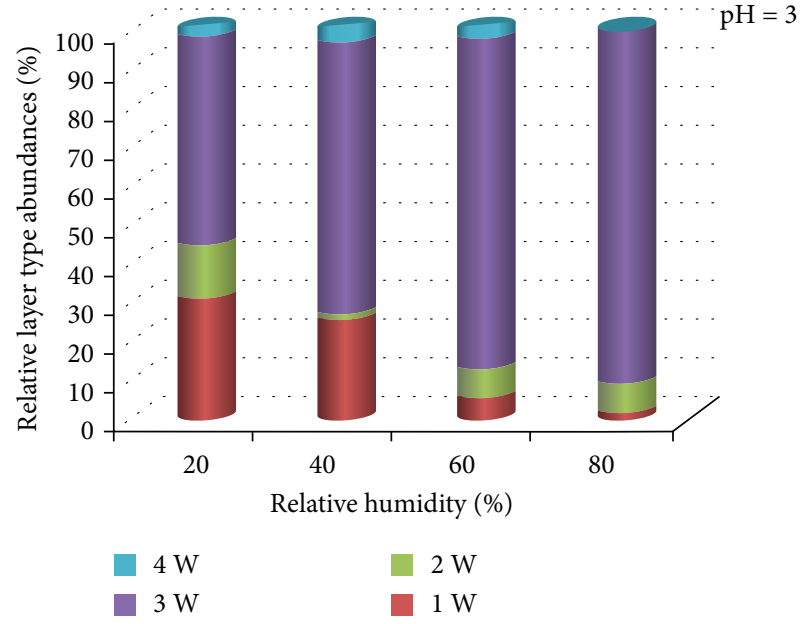

(a)

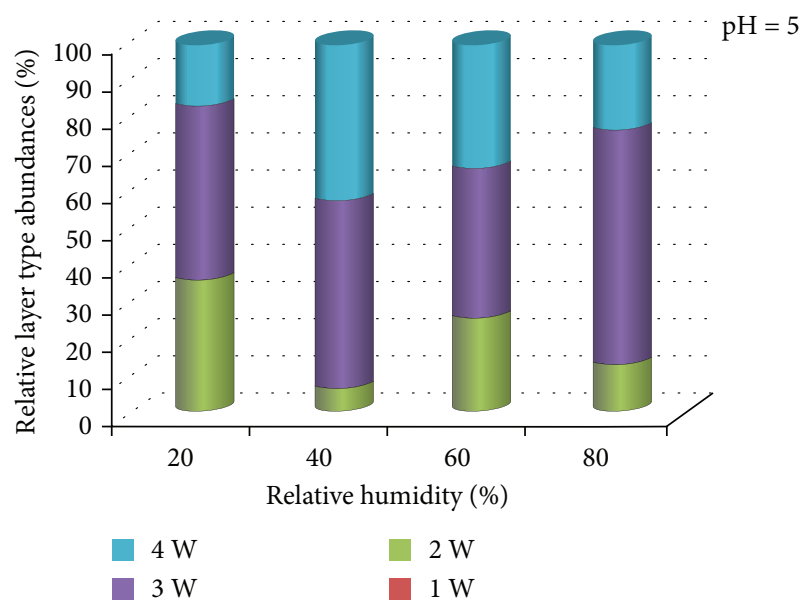

(c)

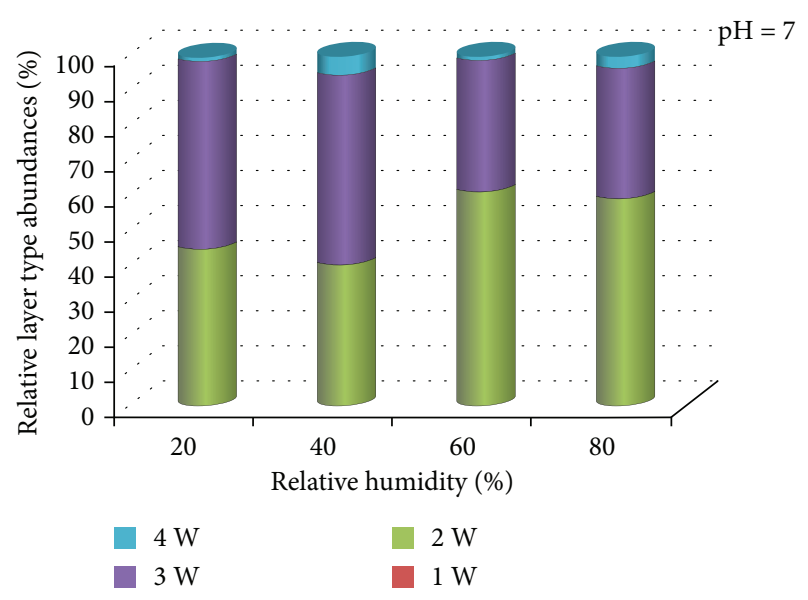

(e)

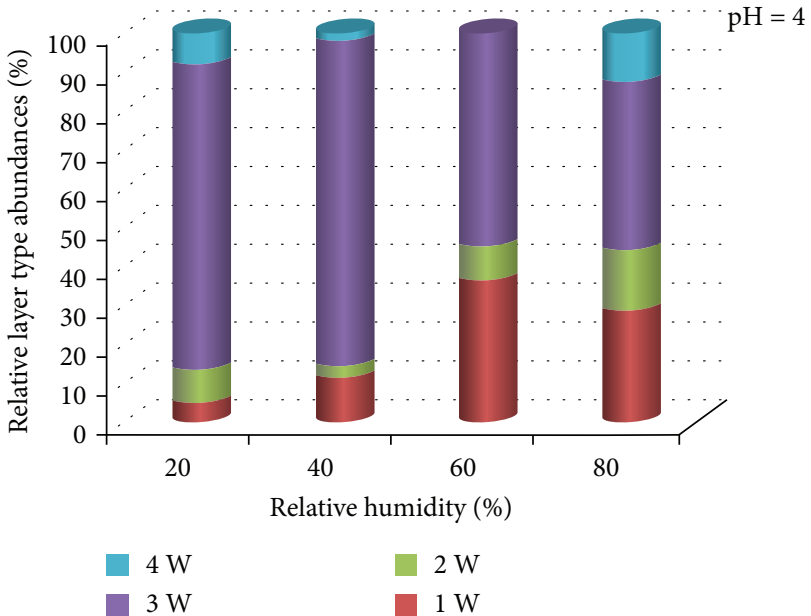

(b)

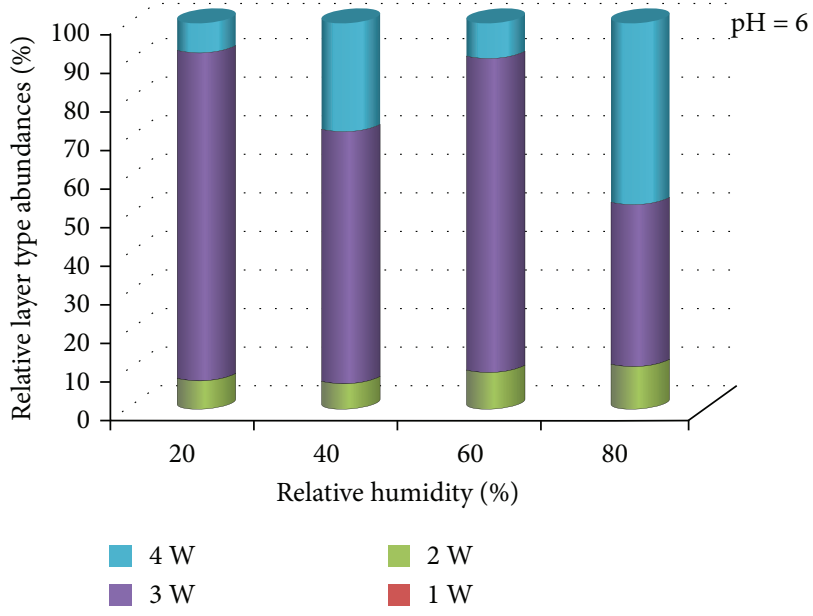

(d)

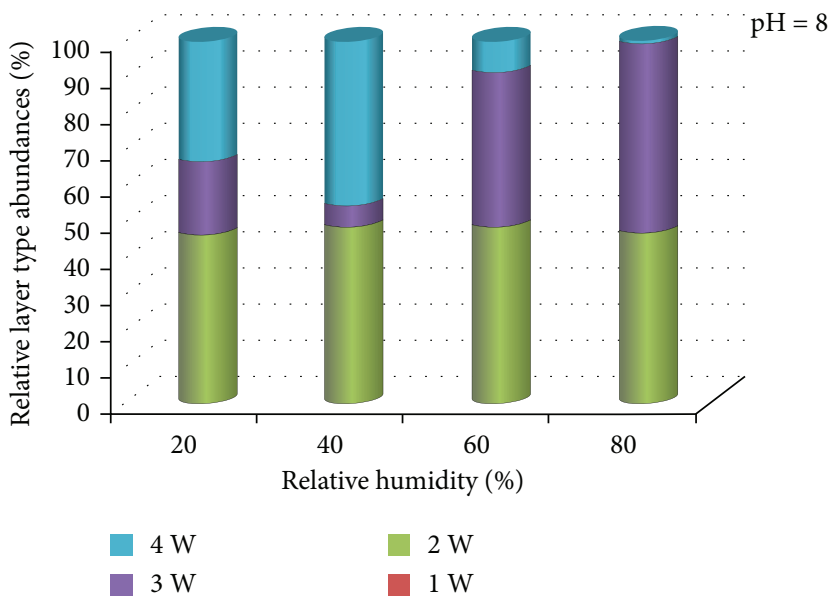

(f)

Figure 9: (a-f) Relative layer type abundances versus \% RH for $\mathrm{pH}$ varying from 3 to 8 .

\section{Conclusions}

The qualitative investigation of the 001 reflection obtained from XRD patterns has implied $\mathrm{pH}$-dependent intercalation of TC within Na-exchanged montmorillonite but remains without real contribution to the understanding of the resulting interstratified structures. In this work, a correlation between results obtained from the XRD modeling 
approach, FTIR, SEM, and BET-BJH method is employed to exceed insufficient results obtained by the simple qualitative XRD analysis.

Obtained results demonstrate the following:

(i) For a low $\mathrm{pH}$ value $(\mathrm{pH}=3)$, clay "particle" is characterized by a random MLS distribution

(ii) By increasing the $\mathrm{pH}$ value, a segregated MLS distribution trend appears indicating the TC molecule intercalation process

(iii) The quasihomogeneous $2 \mathrm{~W}$ phases (obtained, respectively, at $\mathrm{pH} 7$ and $\mathrm{pH} 8$ ), attributed to unexfoliated smectite layers, are fully described using "in situ” XRD analysis

(iv) The $4 \mathrm{~W}$ hydration state (at $\mathrm{pH}=4$ ) is accompanied by a probable TC molecule conformation change

(v) The IR spectroscopy shows that the $\mathrm{pH}$ variation did not really affect the structure except for $\mathrm{pH}$ values close to 7 which confirms the obtained XRD results

(vi) The SEM images show clear surface homogeneity changes as a function of the $\mathrm{pH}$ value, and for $\mathrm{pH}$ close to 7 , the porosity increases probably

(vii) SEM observations are confirmed by BET-BJH adsorption measurements which confirm a possible TC molecule conformation change from $\mathrm{pH} 7$

\section{Data Availability}

No data were used to support this study.

\section{Conflicts of Interest}

The author declares no conflict of interest.

\section{Acknowledgments}

The editorial assistance of the guest editor is acknowledged.

\section{References}

[1] A. C. Q. Ladeira and C. A. Morais, "Effect of ammonium, carbonate and fluoride concentration on the uranium recovery by resins," Radiochimica Acta, vol. 93, no. 4, pp. 207-209, 2005.

[2] S. Kulkarni, A. Ballal, and S. K. Apte, "Bioprecipitation of uranium from alkaline waste solutions using recombinant Deinococcus radiodurans," Journal of hazardous materials, vol. 262, pp. 853-861, 2013.

[3] P. Gu, S. Zhang, X. Li et al., "Recent advances in layered double hydroxide-based nanomaterials for the removal of radionuclides from aqueous solution," Environmental Pollution, vol. 240, pp. 493-505, 2018.

[4] W. Liu, R. Yin, X. Xu, L. Zhang, W. Shi, and X. Cao, "Structural engineering of low-dimensional metal-organic frameworks: synthesis, properties, and applications," Advancement of Science, vol. 6, no. 12, p. 1802373, 2019.
[5] D. Fernández-Calviño, A. Bermúdez-Couso, M. Arias-Estévez et al., "Competitive adsorption/desorption of tetracycline, oxytetracycline and chlortetracycline on two acid soils: stirred flow chamber experiments," Chemosphere, vol. 134, pp. 361366, 2015.

[6] B. Oliver-Rodríguez, A. Zafra-Gómez, M. S. Reis et al., "Widerange and accurate modeling of linear alkylbenzene sulfonate (LAS) adsorption/desorption on agricultural soil," Chemosphere, vol. 138, pp. 148-155, 2015.

[7] Y. Keren, M. Borisover, and N. Bukhanovsky, "Sorption interactions of organic compounds with soils affected by agricultural olive mill wastewater," Chemosphere, vol. 138, no. 10, pp. 462-468, 2015.

[8] F. Tong, X. Gu, C. Gu, R. Ji, Y. Tan, and J. Xie, "Insights into tetrabromobisphenol A adsorption onto soils: Effects of soil components and environmental factors," Science of the Total Environment, vol. 536, pp. 582-588, 2015.

[9] P. Sellin and O. X. Leupin, "The use of clay as an engineered barrier in radioactive-waste management - a review," Clays and Clay Minerals, vol. 61, no. 6, pp. 477-498, 2013.

[10] T. Missana, U. Alonso, and M. García-Gutiérrez, "Experimental study and modelling of selenite sorption onto illite and smectite clays," Journal of Colloid and Interface Science, vol. 334, no. 2, pp. 132-138, 2009.

[11] E. Castellini, D. Malferrari, F. Bernini et al., "Baseline studies of the Clay Minerals Society source clay montmorillonite stx-1b," Clays and Clay Minerals, vol. 65, no. 4, pp. 220-233, 2017.

[12] R. Chalghaf, W. Oueslati, M. Ammar, H. B. Rhaiem, and A. B. H. Amara, "Effect of temperature and $\mathrm{pH}$ value on cation exchange performance of a natural clay for selective $\left(\mathrm{Cu}^{2+}, \mathrm{Co}^{2+}\right)$ removal: equilibrium, sorption and kinetics," Progress in Natural Science, vol. 23, no. 1, pp. 23-35, 2013.

[13] P. Komadel, J. Madejová, and J. Bujdák, "Preparation and properties of reduced-charge smectites - a review," Clays and Clay Minerals, vol. 53, no. 4, pp. 313-334, 2005.

[14] K. F. Yan, X. S. Li, C. G. Xu, Q. N. Lv, and X. K. Ruan, "Molecular dynamics simulation of the intercalation behaviors of methane hydrate in montmorillonite," Journal of Molecular Modeling, vol. 20, no. 6, 2014.

[15] F. Claret, A. Bauer, T. Schäfer, L. Griffault, and B. Lanson, "Experimental investigation of the interaction of clays with high-pH solutions: a case study from the Callovo-Oxfordian formation, Meuse-Haute Marne underground laboratory (France)," Clays and Clay Minerals, vol. 50, no. 5, pp. 633646, 2002.

[16] S. Dultz and J. Bors, "Organophilic bentonites as adsorbents for radionuclides: II. Chemical and mineralogical properties of HDPy-montmorillonite," Applied Clay Science, vol. 16, no. 1-2, pp. 15-29, 2000.

[17] S. Dultz, B. Riebe, and C. Bunnenberg, "Temperature effects on iodine adsorption on organo-clay minerals," Applied Clay Science, vol. 28, no. 1-4, pp. 17-30, 2005.

[18] P. Kulshrestha, R. F. Giese, and D. S. Aga, "Investigating the molecular interactions of oxytetracycline in clay and organic matter: insights on factors affecting its mobility in soil," Environmental Science \& Technology, vol. 38, no. 15, pp. 40974105, 2004.

[19] R. A. Figueroa and A. A. Mackay, "Sorption of oxytetracycline to iron oxides and iron oxide-rich soils," Environmental Science \& Technology, vol. 39, no. 17, pp. 6664-6671, 2005. 
[20] J. R. V. Pils and D. A. Laird, "Sorption of tetracycline and chlortetracycline on $\mathrm{K}$ - and Ca-saturated soil clays, humic substances, and clay-humic complexes," Environmental Science \& Technology, vol. 41, no. 6, pp. 1928-1933, 2007.

[21] M. E. Parolo, M. J. Avena, M. C. Savini, M. T. Baschini, and V. Nicotra, "Adsorption and circular dichroism of tetracycline on sodium and calcium-montmorillonites," Colloids and Surfaces A: Physicochemical and Engineering Aspects, vol. 417, pp. 57-64, 2013.

[22] Y. Zhao, X. Gu, S. Li, R. Han, and G. Wang, "Insights into tetracycline adsorption onto kaolinite and montmorillonite: experiments and modeling," Environmental Science and Pollution Research, vol. 22, no. 21, pp. 17031-17040, 2015.

[23] H. Wu, H. Xie, G. He, Y. Guan, and Y. Zhang, "Effects of the $\mathrm{pH}$ and anions on the adsorption of tetracycline on iron-montmorillonite," Applied Clay Science, vol. 119, pp. 161-169, 2016.

[24] L. Aristilde, B. Lanson, J. Miéhé-Brendlé, C. Marichal, and L. Charlet, "Enhanced interlayer trapping of a tetracycline antibiotic within montmorillonite layers in the presence of $\mathrm{Ca}$ and Mg," Journal of Colloid and Interface Science, vol. 464, pp. 153-159, 2016.

[25] M. Karpov, B. Seiwert, V. Mordehay, T. Reemtsma, T. Polubesova, and B. Chefetz, "Transformation of oxytetracycline by redox-active $\mathrm{Fe}(\mathrm{III})$ - and $\mathrm{Mn}(\mathrm{IV})$-containing minerals: processes and mechanisms," Water Research, vol. 145, pp. 136-145, 2018.

[26] M. E. R. Jalil, F. Toschi, M. Baschini, and K. Sapag, "Silica pillared montmorillonites as possible adsorbents of antibiotics from water media," Applied Sciences, vol. 8, no. 8, p. 1403, 2018.

[27] L. Xu, H. Li, W. A. Mitch, S. Tao, and D. Zhu, "Enhanced phototransformation of tetracycline at smectite clay surfaces under simulated sunlight via a Lewis-base catalyzed alkalization mechanism," Environmental Science \& Technology, vol. 53, no. 2, pp. 710-718, 2018.

[28] C. Aguzzi, C. Viseras, P. Cerezo et al., "Influence of dispersion conditions of two pharmaceutical grade clays on their interaction with some tetracyclines," Applied Clay Science, vol. 30, no. 2, pp. 79-86, 2005.

[29] L. Aristilde, B. Lanson, and L. Charlet, "Interstratification patterns from the $\mathrm{pH}$-dependent intercalation of a tetracycline antibiotic within montmorillonite layers," Langmuir, vol. 29, no. 14, pp. 4492-4501, 2013.

[30] S. Pirillo, C. R. Luna, I. López-Corral, A. Juan, and M. J. Avena, "Geometrical and electronic properties of hydrated sodium montmorillonite and tetracycline montmorillonite from DFT calculations," Journal of Physical Chemistry C, vol. 119, no. 28, pp. 16082-16088, 2015.

[31] H. Zhu, X. Xiao, Z. Guo et al., “Adsorption of vanadium (V) on natural kaolinite and montmorillonite: characteristics and mechanism," Applied Clay Science, vol. 161, pp. 310-316, 2018.

[32] J. Ma, Y. Lei, M. A. Khan et al., “Adsorption properties, kinetics \& thermodynamics of tetracycline on carboxymethylchitosan reformed montmorillonite," International Journal of Biological Macromolecules, vol. 124, pp. 557-567, 2019.

[33] K. S. D. Premarathna, A. U. Rajapaksha, N. Adassoriya et al., "Clay-biochar composites for sorptive removal of tetracycline antibiotic in aqueous media," Journal of Environmental Management, vol. 238, pp. 315-322, 2019.
[34] G. Lv, Z. Li, L. Elliott, M. J. Schmidt, M. P. MacWilliams, and B. Zhang, "Impact of tetracycline-clay interactions on bacterial growth," Journal of Hazardous Materials, vol. 370, pp. 91-97, 2019.

[35] R. Prewo and J. J. Stezowski, "Chemical-structural properties of tetracycline derivatives. 3 . The integrity of the conformation of the nonionized free base," American Chemical Society, vol. 99, no. 4, pp. 1117-1121, 1977.

[36] J. Tolls, "Sorption of veterinary pharmaceuticals in soils: a review," Environmental Science \& Technology, vol. 35, no. 17, pp. 3397-3406, 2001.

[37] M. E. Parolo, M. C. Savini, J. M. Valles, M. T. Baschini, and M. J. Avena, "Tetracycline adsorption on montmorillonite: $\mathrm{pH}$ and ionic strength effects," Applied Clay Science, vol. 40, no. 1-4, pp. 179-186, 2008.

[38] P.-H. Chang, Z. Li, W.-T. Jiang, and J.-S. Jean, "Adsorption and intercalation of tetracycline by swelling clay minerals," Applied Clay Science, vol. 46, no. 1, pp. 27-36, 2009.

[39] W. Oueslati, H. Ben Rhaiem, M. S. Karmous, S. Naaman, and A. B. H. Amara, "Study of the structural evolution and selectivity of Wyoming montmorillonite in relation with the concentration of $\mathrm{Cu} 2+$ and $\mathrm{Ni2}+$, Z Zeitschrift für Kristallographie, vol. 2006, suppl_23_2006, pp. 425-429, 2006.

[40] W. Oueslati, H. Ben Rhaiem, and A. Ben Haj Amara, "Effect of relative humidity constraint on the metal exchanged montmorillonite performance: an XRD profile modeling approach," Applied Surface Science, vol. 261, pp. 396-404, 2012.

[41] W. F. Moll, "Baseline studies of the Clay Minerals Society source clays: geological origin," Clays and Clay Minerals, vol. 49, no. 5, pp. 374-380, 2001.

[42] D. Borden and R. F. Giese, "Baseline studies of the Clay Minerals Society source clays: cation exchange capacity measurements by the ammonia-electrode method," Clays and Clay Minerals, vol. 49, no. 5, pp. 444-445, 2001.

[43] M. Ammar, W. Oueslati, N. Chorfi, and A. B. H. Amara, "The water retention mechanism of a $\mathrm{Cs}+$ and $\mathrm{Na}+$ exchanged montmorillonite: effect of relative humidity and ionic radius on the interlayer," Powder Diffraction, vol. 30, no. S1, pp. S70-S75, 2015.

[44] L. Lambs, B. Decock-Le Reverend, H. Kozlowski, and G. Berthon, "Metal ion-tetracycline interactions in biological fluids. 9. Circular dichroism spectra of calcium and magnesium complexes with tetracycline, oxytetracycline, doxycycline, and chlortetracycline and discussion of their binding modes," Inorganic Chemistry, vol. 27, no. 17, pp. 3001-3012, 1988.

[45] Z. Qiang and C. Adams, "Potentiometric determination of acid dissociation constants ( $\mathrm{pKa}$ ) for human and veterinary antibiotics," Water Research, vol. 38, no. 12, pp. 2874-2890, 2004.

[46] G. Caminati and M. Puggelli, "Europium in phospholipid nanoscaffolds for the photophysical detection of antibiotic traces in solution," in Europium: compounds, production and applications, pp. 203-228, Nova Science Publishers Inc., New York, 2011.

[47] W. Oueslati, H. B. Rhaiem, and A. B. H. Amara, "XRD investigations of hydrated homoionic montmorillonite saturated by several heavy metal cations," Desalination, vol. 271, no. 1-3, pp. 139-149, 2011.

[48] W. Oueslati, M. Ammar, and N. Chorfi, "Quantitative XRD analysis of the structural changes of Ba-exchanged 
montmorillonite: effect of an in situ hydrous perturbation," Minerals, vol. 5, no. 3, pp. 507-526, 2015.

[49] E. Ferrage, B. Lanson, L. J. Michot, and J. L. Robert, "Hydration properties and interlayer organization of water and ions in synthetic Na-smectite with tetrahedral layer charge. Part 1. Results from X-ray diffraction profile modeling," The Journal of Physical Chemistry C, vol. 114, no. 10, pp. 4515-4526, 2010.

[50] M. Ammar, W. Oueslati, H. Ben Rhaiem, and A. Ben Haj Amara, "XRD profile modeling approach tools to investigate the effect of charge location on hydration behavior in the case of metal exchanged smectite," Powder Diffraction, vol. 28, no. S2, pp. S284-S300, 2013.

[51] V. A. Drits and C. Tchoubar, "X-ray diffraction by disordered lamellar structures: feory and applications to microdivided silicates and carbons," Springer, Berlin, 1990.

[52] B. Lanson, "Modelling of X-ray diffraction profiles: investigation of defective lamellar structure crystal chemistry," EMU Notes in Mineralogy, vol. 11, pp. 151-202, 2011.

[53] W. Oueslati and M. Meftah, "Discretization of the water uptake process of Na-montmorillonite undergoing atmospheric stress: XRD modeling approach," Advances in Materials Science and Engineering, vol. 2018, 17 pages, 2018.

[54] J. Madejová and P. Komadel, "Baseline studies of the Clay Minerals Society source clays: infrared methods," Clays and Clay Minerals, vol. 49, no. 5, pp. 410-432, 2001.

[55] C. F. Leypold, M. Reiher, G. Brehm et al., "Tetracycline and derivatives-assignment of IR and Raman spectra via DFT calculations," Physical Chemistry Chemical Physics, vol. 5, no. 6, pp. 1149-1157, 2003.

[56] M. Benzina and A. Bellagi, "Détermination des propriétés du réseau poreux de matériau argileux par les techniques d'adsorption d'azote et de porosimétrie au mercure en vue de leur utilisation pour la récupération des gaz," Annals of Chemistry Science Materials, vol. 15, pp. 315-335, 1990.

[57] S. Gregg and K. Sing, Adsorption, Surface Area and Porosity, Academic Press, London, second ed. edition, 1982.

[58] J. C. Groen, L. A. A. Peffer, and J. Pérez-Ramírez, "Pore size determination in modified micro- and mesoporous materials. Pitfalls and limitations in gas adsorption data analysis," Microporous and Mesoporous Materials, vol. 60, no. 1-3, pp. 1-17, 2003.

[59] E. P. Barrett, L. G. Joyner, and P. P. Halenda, "The determination of pore volume and area distributions in porous substances. I. Computations from nitrogen isotherms," Journal of the American Chemical Society, vol. 73, no. 1, pp. 373-380, 1951.

[60] T. Jesionowski, "Characterization of silicas precipitated from solution of sodium metasilicate and hydrochloric acid in emulsion medium," Powder Technology, vol. 127, no. 1, pp. 56-65, 2002.

[61] N. Yildiz, Z. Aktas, and A. Calimli, "Sulphuric acid activation of a calcium bentonite," Particulate Science and Technology, vol. 22, no. 1, pp. 21-33, 2004.

[62] K. Song and G. Sandi, "Characterization of montmorillonite surfaces after organosilane modification," Clays and Clay Minerals, vol. 49, no. 2, pp. 119-125, 2001.

[63] W. Wang, P. Liu, M. Zhang, J. Hu, and F. Xing, "The pore structure of phosphoaluminate cement," Open Journal of Composite Materials, vol. 02, no. 03, pp. 104-112, 2012.

[64] F. Rouqueral, J. Rouqueral, and K. Sing, Adsorption by Powder and Porous Solids, Academic Press, London, 1999.
[65] M. Önal and Y. Sarıkaya, "Preparation and characterization of acid-activated bentonite powders," Powder Technology, vol. 172, no. 1, pp. 14-18, 2007.

[66] H. Noyan, M. Önal, and Y. Sarikaya, "The effect of sulphuric acid activation on the crystallinity, surface area, porosity, surface acidity, and bleaching power of a bentonite," Food Chemistry, vol. 105, no. 1, pp. 156-163, 2007. 


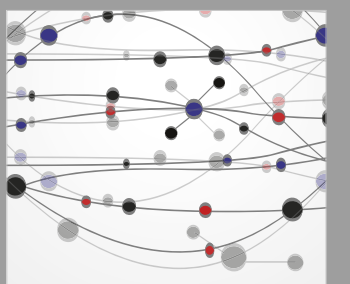

The Scientific World Journal
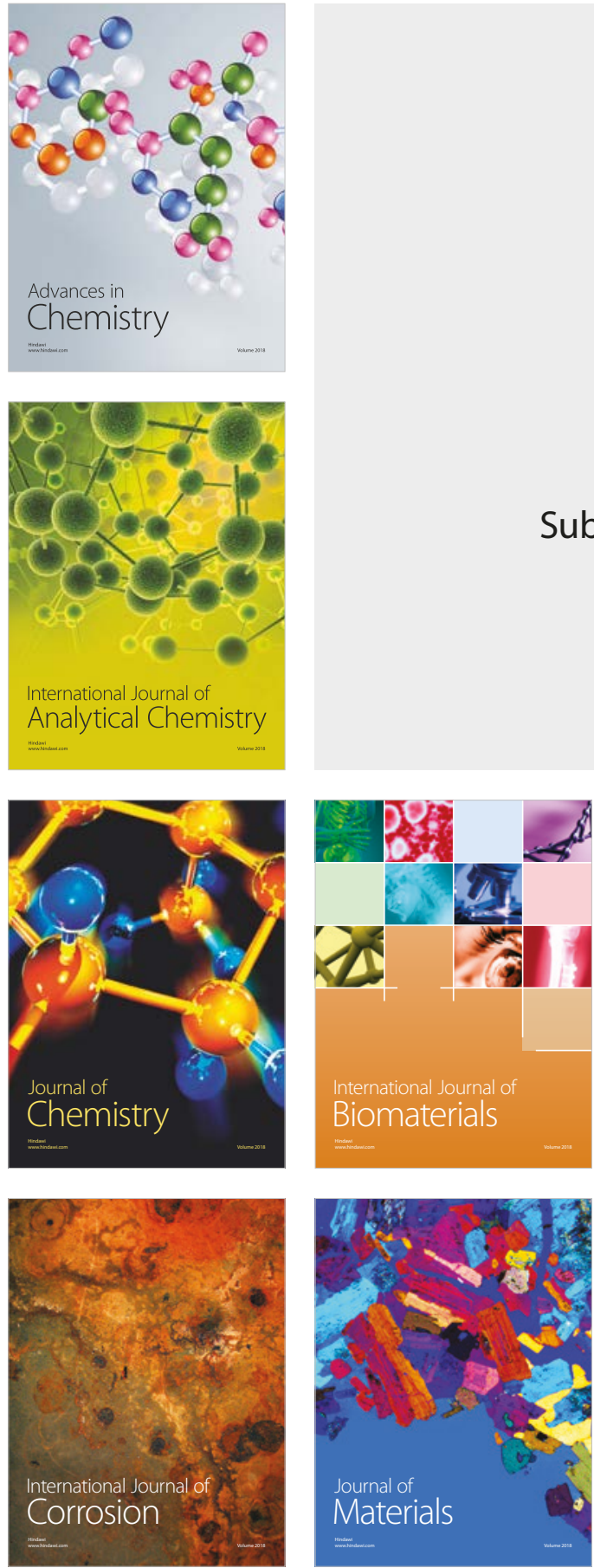

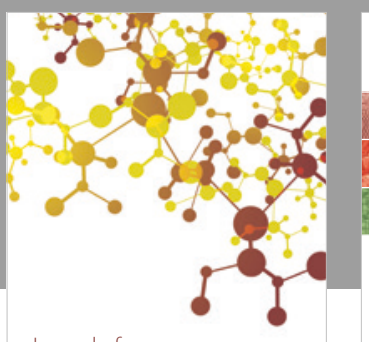

Journal of

Applied Chemistry
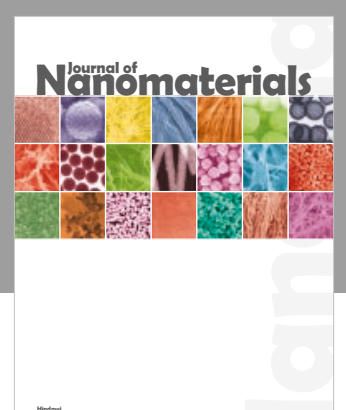

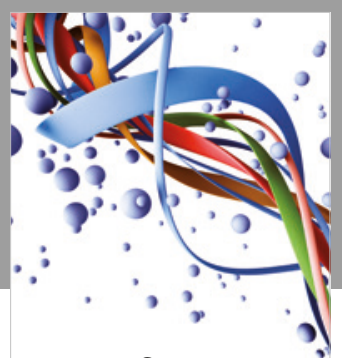

Scientifica

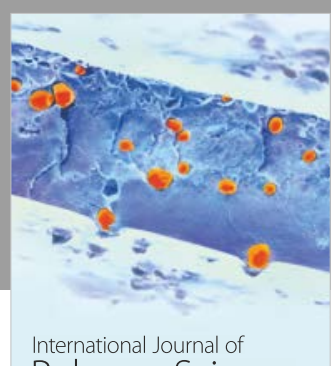

Polymer Science

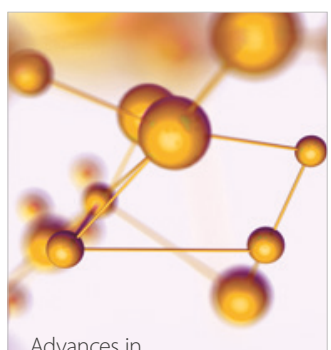

Physical Chemistry
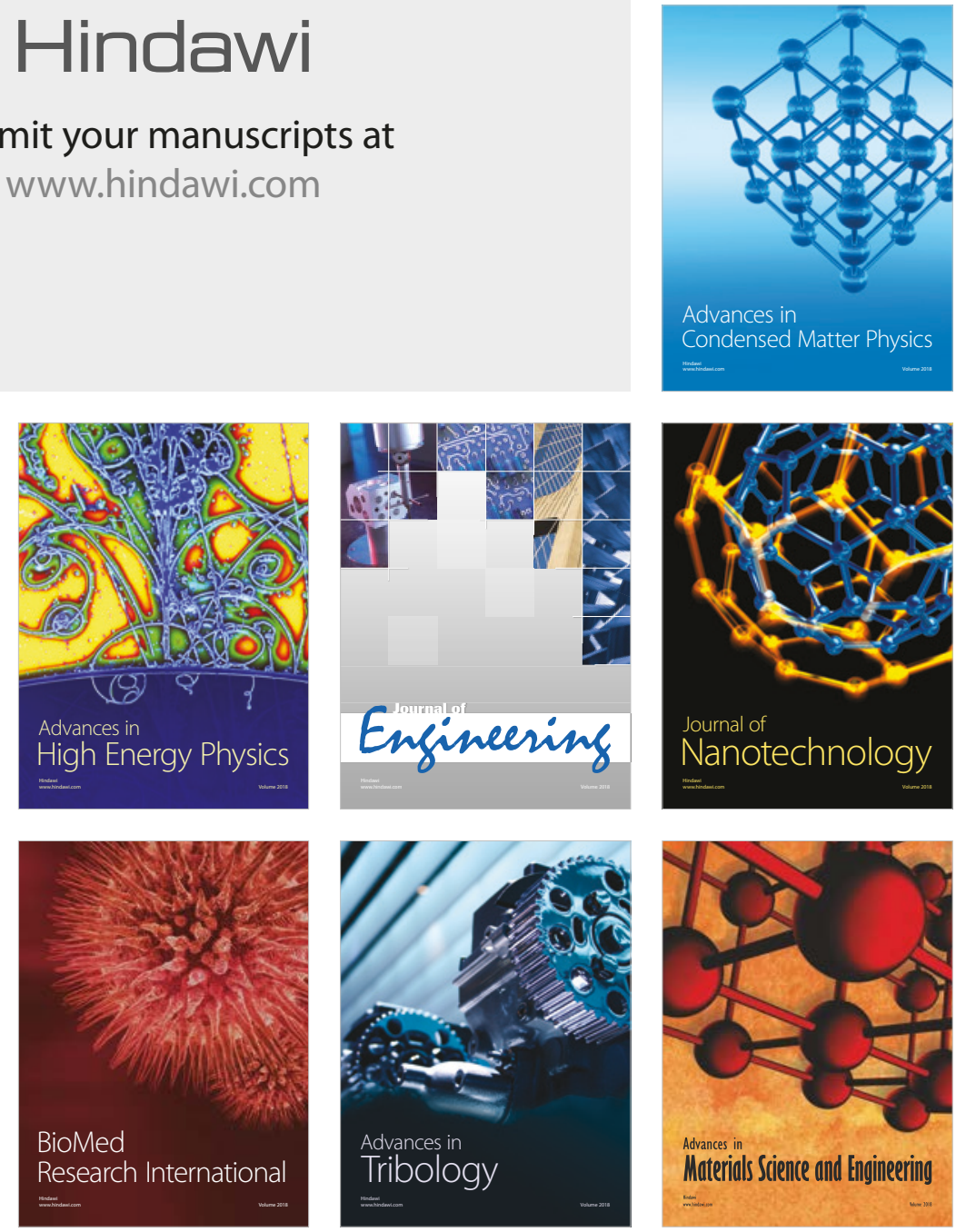